\title{
Sequencing Fiscal Decentralization
}

\author{
Roy Bahl \\ and \\ Jorge Martinez-Vazquez* \\ Andrew Young School of Policy Studies \\ Georgia State University \\ Atlanta, Georgia 30303
}

\section{World Bank Policy Research Working Paper 3914, May 2006}

The Policy Research Working Paper Series disseminates the findings of work in progress to encourage the exchange of ideas about development issues. An objective of the series is to get the findings out quickly, even if the presentations are less than fully polished. The papers carry the names of the authors and should be cited accordingly. The findings, interpretations, and conclusions expressed in this paper are entirely those of the authors. They do not necessarily represent the view of the World Bank, its Executive Directors, or the countries they represent. Policy Research Working Papers are available online at http://econ.worldbank.org.

\footnotetext{
* The authors are Professors of Economics, The Andrew Young School of Policy Studies, Georgia State University. This paper was prepared for the World Bank's Decentralization and Subnational Economics Thematic Group, with financial support from the Danish Trust Fund. Annexes are available on request from the authors. An earlier version of this paper was presented at a half-day seminar April 25, 2005 during the World Bank’s Poverty Reduction and Economic Management (PREM) Learning Week.
} 


\section{Table of Contents}

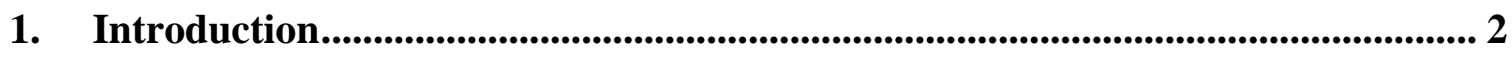

2. Conceptual Framework.................................................................................................. 3

2.1. A Normative Approach to Sequencing .................................................... 3

2.2. Deconcentration before Decentralization?................................................. 5

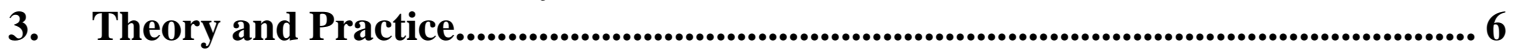

3.1. The National Debate About Fiscal Decentralization....................................... 6

3.2. Reasons for Decentralization.................................................................. 6

3.3. Who Should Participate in the National Discussion?.................................... 8

3.4. The Format for Discussion .................................................................. 10

3.5. The Champions .............................................................................. 11

4. Policy Design ............................................................................................................... 11

4.1. The White Paper ................................................................................ 11

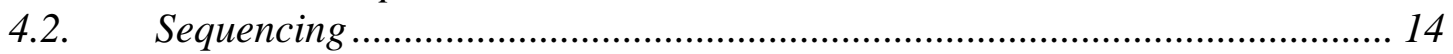

4.3. Fiscal Decentralization Policy Should Be Comprehensive ........................... 14

4.4. The Critical Role of Political Accountability................................................ 15

4.5. Finance Should Follow Function................................................................... 16

4.6. The Significance of Local Revenue Autonomy ............................................. 22

4.7. Design of the Intergovernmental Transfer System......................................... 23

4.8. Subnational Governments Must Face a Hard Budget Constraint ................. 23

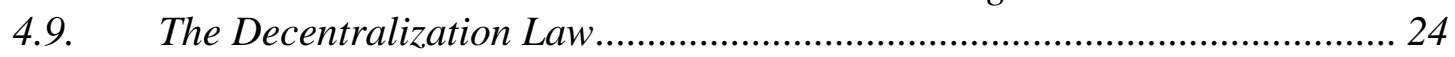

4.10. Implementing Regulations ........................................................................ 26

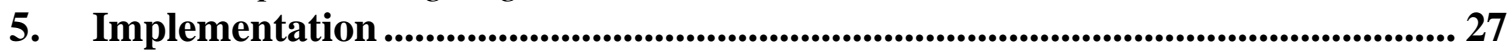

5.1. Transition Measures: Asymmetric Decentralization .................................... 28

5.2. Building Capacity ................................................................................ 29

5.3. Contingency Funds ................................................................................... 30

Big Bang or Gradual Implementation? .......................................................... 30

Transition Measures: Hold Harmless versus “Cold Turkey” .......................... 31

6. Monitoring and Evaluation.......................................................................................... 33

7. Breaches in Sequencing: Causes and Risks................................................................... 34

7.1. Sequencing Does Not Matter? .................................................................. 34

7.2. Sequencing Matters..................................................................................... 36

7.3. Why Do Countries Deviate from Optimal Sequencing? ................................. 36

7.4. Risks Associated with Sequencing Mistakes ................................................... 37

High-Risk Sequencing Choices ............................................................... 38

Lower Risk Sequencing Mistakes........................................................... 40

\section{List of Tables and Figure}

Table 1: Summary of Selected Decentralization Sequencing Issues in Five Case Countries. 21

Figure 1: Sequencing Fiscal Decentralization: A Normative Approach ........................... 4 


\begin{abstract}
While there is extensive knowledge about how to design fiscal decentralization policies, considerably less is understood about how a decentralization program should be sequenced and implemented. Countries embarking on decentralization often struggle with decisions about the essential components of decentralization including the order of an introduction of decentralization policies, the number of years necessary to bring a full program on line, and the components of the transition strategy.

We argue that the sequencing of decentralization policies is an important determinant of its success. The consequences of a poorly sequenced decentralization program can range from minor delays and complications to ineffectiveness and subsequent failing support of decentralization efforts, macroeconomic instability, and fundamental failure in public sector delivery. At a minimum, the strategy of "making it up as we go" will not lead to the same structure of decentralization as will a planned strategy.

The paper raises two questions: First, is there an optimal sequencing for decentralization policies and implementation? Our answer is that there is, and that following these sequencing rules can reduce the costs and risks of implementing fiscal decentralization. Second, to what extent do countries follow these optimal sequencing rules? The answer is, in general, they do not. The gap between theory and practice is a result of the complexity of sequencing design, which discourages fiscal planners from implement the full process. In addition, sequencing requires a sustained discipline and vision for its implementing, as well as overcoming pressures from political actors, especially in developing countries.
\end{abstract}




\section{Introduction}

While there is extensive knowledge about how to design fiscal decentralization policies, considerably less is understood about how a decentralization program should be sequenced and implemented. ${ }^{1}$ Countries embarking on decentralization often struggle with decisions about its essential components, the order of introduction of decentralization policies and activities, the number of years necessary to implement a program fully, and the components of the transition strategy. We argue in this paper that the sequencing of decentralization is an important determinant of its success. The consequences of a poorly sequenced decentralization program can range from minor delays and complications, to ineffectiveness and subsequent failing support of decentralization efforts, to macroeconomic instability, and even to chaotic situations with failed public services.

Logically, and as experience shows, some decentralization measures (e.g., devolution of expenditure responsibilities) may not yield the desired decentralization outcome without a previous complementary reform (e.g., providing for budget autonomy by eliminating mandates), or the effects may even be pernicious (putting revenue decentralization ahead of decisions about expenditure assignment). As we elaborate in this paper, there is ample country evidence, accumulated over several decades that the sequencing of decentralization does matter. At best, the argument that sequencing does not matter may be correct only if one is willing to ignore the adjustment, friction and time costs that may be involved in getting to the "right" decentralization outcome. At a minimum, the strategy of "making it up as we go" will not lead to the same structure of decentralization as will a planned strategy.

If sequencing matters, what is the best way to proceed? There are two ways to develop guidelines for sequencing decentralization. One is to offer a normative approach, i.e. in a world without political and administrative constraints, what is the best way to bring a decentralization strategy on line? We propose such an approach in the next section of this paper. The other approach is to distill real-world lessons about sequencing decentralization by studying the practice, which reflects the political economy issues that intervene in the process of designing and implementing a fiscal decentralization program. In this paper, we consider the practice in some detail in five countries-Indonesia, India, Mexico, Russia, and Tanzania_-and comment on the experience in several others. These five countries were chosen for special attention because they represent various, ongoing decentralization processes around the world, and provide a good cross section of sequencing experience. This international practice shows there is no single best approach to sequencing fiscal decentralization and that that one formula will not produce the same results in every country.

\footnotetext{
${ }^{1}$ A few papers have addressed this question. See for example, Spahn (2005) and GTZ/CONAM (2002).
} 


\section{Conceptual Framework}

\subsection{A Normative Approach to Sequencing}

Our version of the normative textbook approach to sequencing fiscal decentralization has six steps, as outlined in Figure 1. This might be argued to be a stylized approach to sequencing decentralization that might serve as a reasonable baseline against which to compare the real world practice, where politics and administrative constraints will certainly rule the day.

There should be a platform of enabling administrative and institutional structures on which the decentralization can be built. One important precondition for effective decentralization is the rule of law for the adjudication of intergovernmental disputes or democratic electoral rules. This is critical given the divergent interests associated with decentralized governance. Other preconditions include the existence of an orderly budget process and fiscal rules. The platform might also include the deconcentration of central government services to the regions. Deconcentration can speed up the process of decentralization because there is already a local experience with managing local service delivery. However, it does not fall into the category of absolute requirements for beginning a decentralization program.

The actual fiscal decentralization process begins with a national debate involving the key stakeholders (Step 1). This debate might be in the context of a national election, sometimes responding to bottom-up demands for local autonomy. Alternatively, it might be part of a discussion led by an appointed national commission to consider a change in the pattern of governance. Either way, a general consensus may be reached about the sentiment for pushing ahead with decentralization and some clear "champions" of decentralization should emerge. This would seem necessary if the decentralization program is to stay on track and be sustainable. 
Figure 1: Sequencing Fiscal Decentralization: A Normative Approach

FIGURE 1

\section{Sequencing Fiscal Decentralization: A Normative Approach}

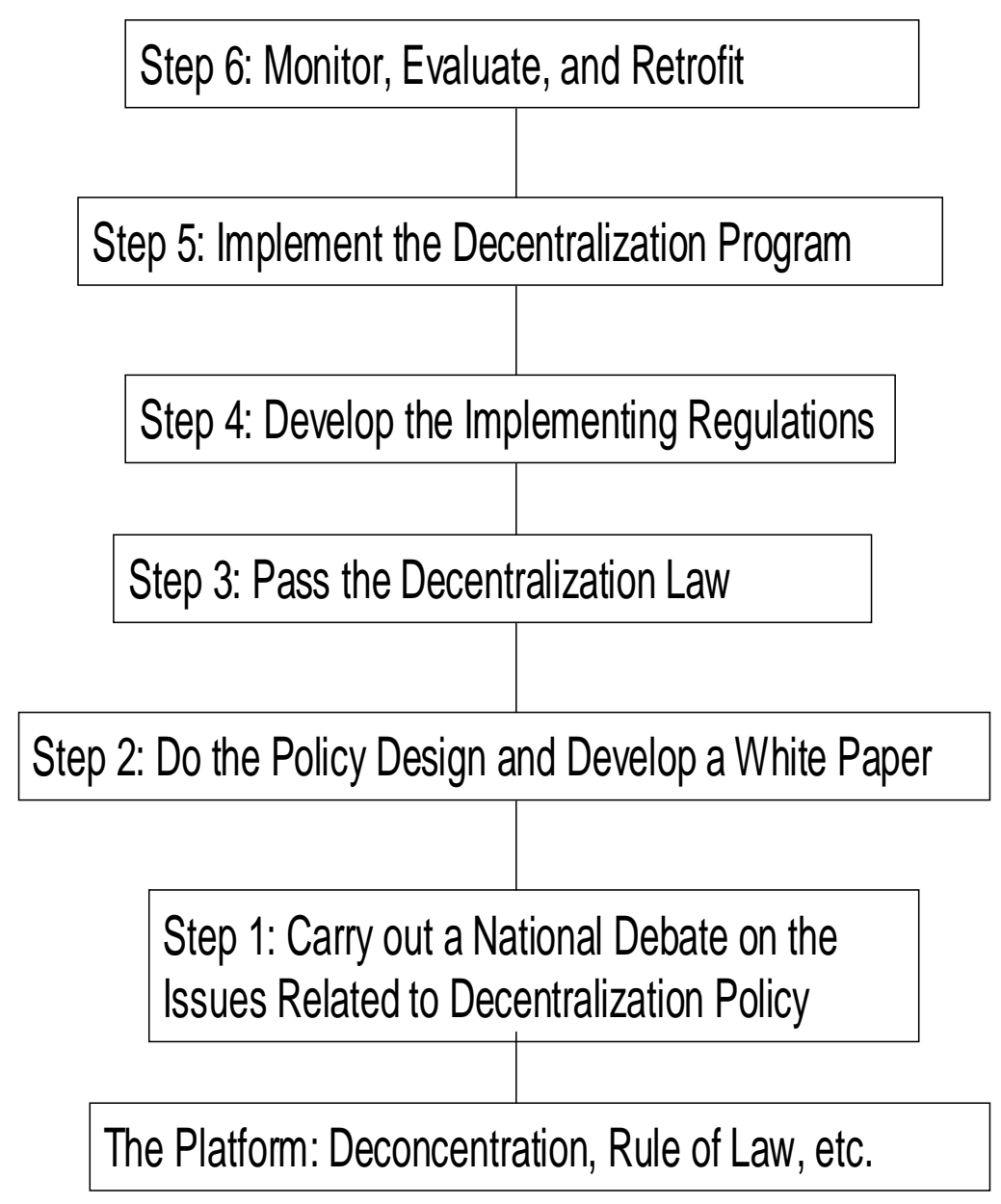

The second step is the design of the fiscal decentralization program, culminating in a policy paper or a framework for the fiscal decentralization. While the national consensus might be around the broad idea of moving government closer to the people, the White Paper would lay out the government's plan for accomplishing this. It would outline the main components of the fiscal decentralization program, provide a timetable for implementation and serve as the basis for writing the law.

Step three is to draft and pass the decentralization law(s). This naturally follows on from the national mandate and from the policy framework paper, and it gives legal standing to the implementation of the fiscal decentralization measures. The law must be 
clear and it must be true to the policy design. The decentralization law might stand alone, or some elements of the decentralization program might become part of the constitution.

Step four is to adopt a set of implementing regulations that spell out the detail of how the fiscal decentralization will be put in place. For example, the White Paper and the law might call for the transfer of civil servants from central to subnational governments. The implementing regulations on the other hand, would spell out the detail of this transfer. Essentially, the implementing regulations are written for those government officials — central and local—who would put the new system in place.

Step five is implementation, which involves a multitude of tasks. Following a very clear set of rules and regulations, the central and subnational governments begin assuming their new fiscal responsibilities and so on.

Step six involves a well-designed and operational system of monitoring and evaluation by the central (state) government and a well laid out accountability system at the subnational level.

The steps outlined above might be thought of as a normative approach to ordering the elements of a sustainable fiscal decentralization strategy. This sequencing allows each step to build on the necessary prerequisites, and therefore could minimize the chances for failure of the system to accomplish its objectives. In the real world, however, there are important constraints that steer countries away from such an optimal sequencing. And sometimes, these departures are in the best interests of getting the job done. But clearly, while some departures may be admissible in terms of the costs and disruption involved in the decentralization process (for example, getting the implementation started without complete implementing regulations), some other departures may be too costly (for example, decentralizing borrowing powers without providing for a hard budget constraint for subnational governments).

In what follows we elaborate on each of these six steps in an optimal sequencing, provide more detail on what is entailed in each, examine the potential costs of ignoring or mishandling each step, and consider how the sequencing steps have been addressed in a number of countries that either have already decentralized or are in the process of doing so. Our goals are to develop amendments to the normative approach outlined in Figure 1, based on the international practice, to identify some of the reasons for deviation, and to assess the risks that can come from making different sequencing decisions.

\subsection{Deconcentration before Decentralization?}

A successful deconcentration of central government service delivery may provide an important platform for implementing decentralization successfully. This platform might include a cadre of central (or state) officers involved in service delivery in the regions. When the decentralization policy is eventually crafted, the local civil service will be more ready to take on the responsibilities assigned to the subnational level, and the risks of extreme disruption of service delivery will be less. This appears to be a major 
reason why Indonesia’s "big bang” decentralization was accomplished without a breakdown in public service delivery. On the other hand, the slow pace and reversals of decentralization policies in many Latin American countries over the past several decades may be linked to initial conditions that did not include deconcentration of public services.

However, one could also make the case, we believe a weaker one, that deconcentration policies may retard the adoption of a fiscal decentralization strategy. Bureaucrats in deconcentrated agencies may resist decentralization to local governments, because they fear loss of their power base or even their job. Moreover, taking the deconcentration step may even reduce the demand for strengthening local government finance by softening political dissatisfaction with existing centralized policies.

\section{Theory and Practice}

\subsection{The National Debate about Fiscal Decentralization}

The momentum for decentralization may originate from the bottom up, as in Russia, Spain or Estonia, from the top down, as in Tanzania, Thailand or Bulgaria, or from both directions as in Mexico, India, or Indonesia. Regardless of where the pressure originates, some form of national discussion about the desirability of decentralization is an important first step in the process. The key political and administrative stakeholders and ultimately the voters must buy into the desirability and general outlines of a fiscal decentralization strategy. Otherwise, fiscal decentralization may not be sustainable. This national discussion should be about the basic goals of the decentralization program and the options that are available for structuring decentralization, but should not dwell on the detail. The idea is to get some general agreement on what fiscal decentralization should accomplish and on how it should change the way government does its business. The national debate that took place in Canada during the last part of the past century on federal-provincial fiscal relationships provides a good example of this.

Ideally, this national debate will involve the main political parties, will have some degree of formality (as in the case of a national commission), and will be transparent (as in the case of a national election). If this is not the first step in the process, it almost certainly will take place later and in that event could prove detrimental or perhaps even fatal to the implementation of the program. A recent example is provided by Moldova where in the past three years an incipient and promising decentralization program got reversed and abandoned once the opposition party took power in the national elections.

\subsection{Reasons for Decentralization}

Decentralization is usually introduced as a policy to offset a problem that has caused dissatisfaction with the present centralized system of governance. Identifying this underlying problem is a crucial step in designing a program that will match up with the demands coming from those who are calling for a change in the present system. 
The identification of the underlying problem, however, depends very much on whose vantage is taken. When viewed through the eyes of the population in general, fiscal decentralization can become a high priority policy issue because of dissatisfaction with the government performance. In a developing country, this often means that they are dissatisfied with the quality of public services that they receive, with their lack of voice in determining outcomes, and with the responsiveness and accountability of government officials. Another possibility is that significant groups of voters feel unconnected to the present governance structure because they are ethnically or culturally different. There may also be a general perception of failure and resentment towards highly centralized models of governance, such as Russia and other countries that are in transition from planned socialism and absolutist regimes.

From the perspective of the central government political players and administrative bureaucracy, however, the underlying rationale may be quite different. Politicians may react opportunistically to a decentralization initiative and support improved citizen participation in governance to gather more political favor, or to act strategically to appease centrifugal, or separatist forces and hold the country together. All of this rhetoric needs to be part of the national discussion because it calls out the relationship between the underlying problems as seen by the population and the policy direction being advocated by government leaders.

The main point in this discussion is that the design of the decentralization program and the sequencing of decentralization policies must follow identification of the primary objectives of the decentralization. The order in which decentralization policies should be introduced in a program driven by one objective may be very different from the best sequencing for a program driven by another primary goal. A national discussion of the reasons for decentralization would seem an absolutely essential first step. Moreover, only by knowing the primary objectives of the program can one evaluate the success of the decentralization strategy. However, identifying the primary objectives of the decentralization may not be an easy task. The objectives that most drive the decentralization strategy can be wrapped in a heavy load of many other contemporary issues. This is well illustrated in the five countries of our focus. (See also the summary in row 1 of Table 1.)

There are some common threads in the rationale for fiscal decentralization in the Indonesian and Russian cases. The celebrated Indonesian "big-bang” decentralization in 2001 was a long-in-the-making policy reform that was driven by a perceived overcentralization of government decision-making and a perceived exploitation of some regions by a very strong and allegedly corrupt Suharto regime. ${ }^{2}$ Independence movements and centrifugal forces in many of the regions in the Russian periphery, especially those with heavy ethnic populations, in combination with a weak center in the midst of a power struggle between President Yeltsin and a communist dominated

\footnotetext{
${ }^{2}$ Two very good discussions of the origins of the Indonesian decentralization program are Rasyid (2004) and Hofman and Kaiser (2004).
} 
parliament, seemed to call for a decentralization program with heavy emphasis on local political control and expenditure autonomy.

Mexico's decentralization was also a reaction to a longstanding perception of too much central control. In 2004, a National Finance Convention was convened with the objective of developing a national consensus on the direction of future decentralization reforms in Mexico. ${ }^{3}$ The impetus for the new drive for decentralization in Mexico has enhanced political competition and demands for greater political decentralization and administrative efficiency. The current policy design of fiscal federalism emphasizes expenditure autonomy and local political control and control over the civil service.

Tanzania's decentralization is being driven more by dissatisfaction with the quality of local public services, which has been attributed to too little expenditure discretion at the local government level. India is likewise attempting to address a problem of too little discretion at the local government level, as well as a problem of fiscal indiscipline at the state government level.

\subsection{Who Should Participate in the National Discussion?}

A national debate about the merits of fiscal decentralization ideally would involve all relevant interest groups, i.e., all of those who see potential benefits or costs from a move toward fiscal decentralization. The discussion will be led by the central government, which ultimately will make the rules of any new decentralization. But the discussion must be inclusive. A basic idea behind decentralization is to empower those at the state and local government level by making them part of the decision-making process. It would be self-defeating to leave them out of the debate. The flip side of this is that much of the central bureaucracy will lose power with decentralization. It would be equally foolish to leave them out of the debate. The goal is to develop as much of a consensus as is possible and to forestall later criticism that the process was not transparent.

But there are important tradeoffs involved. The broader the audience in the national debate, the harder it will be to gain consensus for a program. The result may be a prolonged discussion that finally dies of inertia, or a watered-down program that may not address the underlying problems.

The national debate may be spontaneous, as it was in Indonesia, and all parties can have voice. In other cases, the national discussion is more formal and orchestrated from the top, as in the cases of Tanzania, China, Bulgaria or Vietnam. It is not unusual for the national discussion about decentralization to be the responsibility of a commission or even a Ministry. In such cases, the discussion is led by the higher level government (central or state), as was the case in South Africa. It is a mistake, however, to leave the

\footnotetext{
${ }^{3}$ See the discussion in Webb and Gonzalez (2003) on the difficulties and opportunities Mexico faces in reaching a national consensus for future reforms.
} 
decentralization discussion fully in the hands of the central (or state) government. ${ }^{4}$ The result can be a struggle between central ministries that would gain or lose influence, with potentially little input from the subnational governments, who are the key to making fiscal decentralization succeed.

The Parliament or Legislature also should be part of the national discussion. After the decentralization program is underway, Parliament will be the body that passes or repeals the legislation that supports or defeats the intent of the decentralization program. In fact, if the general framework for decentralization is not in place at the time of implementation, Parliament may well become a principal influence on the shape of the program. This is all the more reason to have Parliament or Congress heavily involved in the initial national debate. However, Parliament alone cannot lead the national discussion because its members may be too politically driven and power is often too unequally divided. Parliament was not a key player in the national debate over decentralization in Indonesia. However, shortly after the program was conceived, Parliament became a principal influence on shaping the decentralization program in its first years.

Parliament in Tanzania played only a minor role. One of the reasons for the introduction of a formula-based transfer system appears to have been that the MOF was tired of being unable to explain to MPs the criteria for distribution of revenues among local governments.

The involvement of subnational governments in the national debate is not easily accomplished because often this sector is not represented in an organized way. Associations of local governments, or of mayors, or governors, should be given voice in the national discussion. For example, in Mexico, the National Conference of Governors (Conago) has emerged as a powerful counterpart to the federal government. However, because their interests diverge (e.g., richer vs. poorer regions, or urban vs. rural local governments), their formal representation may be splintered. In Russia in the mid 1990s, an association representing a small number of the richer regions lobbied the federal government, sometimes quite effectively, on a variety of divisive issues, such as the overall level of interregional redistribution and the sharing of revenues from natural resources. In contrast, the Association of Local Authorities in Tanzania is very weak, and has little impact on the reform process, although the urban areas do appear to have some political power.

It is important that a central ministry not be taken to stand for the interests of local governments. The Ministry of Local Government or Ministry of Home Affairs may be "closest" to the subnational governments on a day-to-day basis, but in many cases are not strong proponents of significantly enhanced local fiscal autonomy. Their primary interest may well be in the direction of not giving up control over the fiscal operations of the

\footnotetext{
${ }^{4}$ A conspicuous example of this kind of mistake is to put the line ministries at the central level in charge of defining decentralization in their respective sectors, such as has been the case in El Salvador, Nicaragua and other Central America countries (see Arze and Martinez-Vazquez, 2004).
} 
local governments. Arguably, this has been the experience with the Ministry of Home Affairs in Indonesia.

Civil society, unions, and representatives of the civil service may be important contributors to the development of a decentralization program. Typically these groups do not find a place at the table in the national discussion, and when they do, their knowledge about the subject of decentralization may be limited to a single issue of self-interest. For example, national teacher and health professional unions have been a serious impediment to the decentralization of education and health services in Mexico. However, informal organizations and NGOs have become increasingly important in fiscal decentralization strategies in many countries and it would be a mistake to ignore them in the national debate.

\subsection{The Format for Discussion}

In what format can the national discussion about decentralization take place? Sometimes, the process itself can play a major role in shaping the kind of decentralization that will be adopted.

The discussion might be prompted by external events and the national debate might be organized as a result of these events. One possibility is that it can be part of a political or economic upheaval, such as the end of apartheid in South Africa or the breakup of the Soviet Union and regime change in Central and Eastern Europe. ${ }^{5}$ In such cases, the national discussion about decentralization can be especially reactionary to the unfairness of the present system, and more prone to lead to an entirely new framework than to adjust the present system. Indonesia and Bosnia-Herzegovina are other cases in point.

In Tanzania, the latest wave of decentralization reforms got started with a National Conference in 1996 under the banner of "Towards a Shared Vision for Local Government in Tanzania.” The results of the conference were incorporated in a strategy document, The Local Government Reform Agenda (LGRA), which in 1998 was endorsed by the Government.

In Indonesia, the process was simply commissioned. The Ministry of Regional Autonomy (later merged into the Ministry of Home Affairs) was commissioned to draw up the law describing the new assignment of expenditure responsibly, the new civil services rules, and the nature of local government autonomy in matters of fiscal management. The Ministry of Finance was commissioned to draft the law on the financing of these local governments including revisions to the system of intergovernmental fiscal transfers.

A second way in which the decentralization discussion might be joined is through the deliberations of an appointed commission. In this case, the reform program might be

${ }^{5}$ See Bahl and Smoke (2003), Wallich (1994), and Bird, Ebel and Wallich (1995). 
less comprehensive, especially if there is no national imperative to make a sweeping change in the system of governance. This has been the situation for over five decades with India's Finance Commissions. ${ }^{6}$ This has also been the case in Russia in the late 1990s when several government commissions were created to suggest alternative paths to reforming equalization transfers and other aspects of the intergovernmental finance system. More recently, President Putin appointed the Kozak commission for the same purpose and the commission recommendations have been highly influential in the reform agenda of the Russian government. ${ }^{7}$

In Pakistan, the military government appointed the National Reconstruction Bureau (NRB) in 1999 and charged it with developing a decentralization plan. Though inputs from all sectors were encouraged, the NRB had a relatively free hand in developing the program. The appointed head of the NRB was a retired general.

In other cases, the national discussion about decentralization may be more conventional and may take place in the context of a regular national or state election, as was the case in Mexico's presidential election of 2000.

\subsection{The Champions}

An important ingredient for the success of fiscal decentralization is a coalition of strong advocates. These advocates, or champions, will keep decentralization in the center of the national debate and will work to develop the coalitions necessary to enact a decentralization policy.

But what if there are no decentralization champions? In theory, the policy design may go on, but in practice what is likely to happen is that the entire process will drag on for years with otherwise minor obstacles becoming insurmountable. The recent experiences of countries like Thailand and Georgia show how the process of decentralization has failed to advance because of a lack of strong champions. For this reason, it is important that the champions become active in the very first steps of the introduction of a fiscal decentralization program.

\section{Policy Design}

\section{1. $\quad$ The White Paper}

Fiscal decentralization is a policy that is designed to achieve certain objectives. Therefore, it is critical that the objectives be clearly specified before the program is designed. The overall framework for the decentralization must be elaborated in a policy paper. This policy paper must be specific enough, and comprehensive enough, to guide

\footnotetext{
${ }^{6}$ India has had twelve successive Finance Commissions with the main role of recommending to Government on center-state revenue sharing and other finance issues. An independent Finance Commission is mandated in the Constitution. See Singh (2004).

${ }^{7}$ See the discussion in Martinez-Vazquez, Timofeev and Boex (2005).
} 
the development of the law and the implementation. And, it must come after the national discussion that gives the mandate for decentralization policy.

What if decentralization goes forward, but there is no such policy paper? Two major problems are almost certain to occur.

First, without a roadmap for the decentralization strategy, government and Parliament will "make it up as they go.” This can lead to pieces of the decentralization strategy that do not fit together, e.g., starting the process by decentralizing revenues before any clear assignment of expenditure functions, mandating an expenditure assignment list that does not match revenues assigned, authorizing borrowing powers with no provision for repayment capacity, building expectations of fiscal responsibility, but making no provision for a hard budget constraint, or assuming that all subnational governments will have the same capacity to implement decentralization programs. Even with a White Paper in place, elected politicians and bureaucrats who are new to the scene might introduce changes that are contradictory and eventually harmful to the objectives of the decentralization. Or, interest groups might prevail in getting policy adjusted to satisfy their own objectives. But this will be much less likely to happen if a framework is clearly in place.

The other problem with not having a documented framework is that later year policy changes may not be consistent with the overall goals for the fiscal decentralization program. It is easier, for example, for Parliament to pass a new decentralization measure and label it as "supportive of the strategy," when the strategy has not been written down. An interesting case in point is Indonesia, where a hold harmless system was put in place by Parliament to protect local government from receiving any reductions in revenues upon the introduction of the new, formula-based system of equalization grants. This hold harmless provision minimized the equalization effects of the new grant regime and helped perpetuate undesirable aspects of the previous system (directly compensating local governments according to the number of their employees.) This was not envisioned in the original program design. Parliament, after year one of the decentralization program, decided to keep this hold harmless system in place. With hindsight, the problem was that there never was a firm plan as to how the new transfer system would be phased in. Of course, Parliament may have overruled any firm plan in favor of its own program in any case, but the existence of a policy paper would have made that more difficult.

The White Paper that frames the decentralization policy needs to cover all of the elements of the program, but it need not cover them in a detail that would be expected in the implementing regulations, nor should it strive to impose a tight timetable where all reforms should happen at once. However, it should be the result of a careful analysis of the options, it should have benefited from review and input from a broad cross-section of stakeholders, and it should propose a realistic timetable with a clear and connected road map of the steps to be taken over the next several years. The White Paper should be a published document in order to give transparency to the process. 
Common sense would seem to dictate the need for an overall framework as an early step in implementing decentralization, yet countries often skip this step (Table 1). Indonesia never did prepare an overall framework and instead went forward with two laws followed by a set of implementing regulations. The result, as discussed below, has been a good bit of "making it up as we go" which has brought some serious challenges and has considerably delayed the decentralization program. ${ }^{8}$ Decentralization has been reasonably successful in Indonesia, despite the absence of a guiding framework. The question to raise is how much more successful it would have been with a framework. Similarly, Russia jumped into the decentralization process in 1992 without preparing an explicit framework and overall strategy. Successive laws and measures were often disconnected and sometimes contradictory. It took Russia almost a decade to issue a comprehensive vision of the decentralization process in what became known as the Kozak Commission Report in 2002. ${ }^{9}$ Mexico’s decentralization policy has continued to drift forwards and sideways without a comprehensive reform blueprint.

Tanzania, on the other hand, did produce a White Paper on local government reform at the beginning of the current phase of decentralization reforms in 1998. While this policy paper does not provide a great amount of detail on planned fiscal adjustments, it lays out the government's general objectives for the program. By persistently emphasizing the theme of “decentralization by devolution,” Tanzania's “Government Policy Paper on Local Government Reform” has continued to inform and order the ongoing reform process quite successfully. Its lack of specific policy reforms may have helped to reduce potential opposition against the reform agenda.

Elsewhere in East Africa, the experience is mixed (NCG, 2004). Uganda adopted a fiscal decentralization strategy in 2002. However, the strategy is not comprehensive and to date is still focused on reforming the system of intergovernmental transfers. Kenya, on the other hand, has identified some areas of local government finance reform, but has not developed a comprehensive strategy.

India is a case apart in this respect. Although there has not been a fundamental White Paper mapping out the reform of India’s federalism, every five years, India's Finance Commission issues a comprehensive report on intergovernmental finance issues and options for reform.

\footnotetext{
${ }^{8}$ The problems that arose from no real fiscal decentralization plan were recognized by the government, and in 2002, the Ministry of Finance issued a draft "White Paper" on Fiscal Decentralization (Ministry of Finance, 2002). Though the basic objectives and policies were aired out, this document was not the result of a broad national discussion. It could however, be an input to redrafting the original laws, an exercise that was underway at the time of this writing.

${ }^{9}$ After the August 1998 ruble crisis, a wide reform process, such as the Budget Code and Tax Code, gained new momentum and the Government issued a document that can also be considered a White Paper under the title of "Concept of reform of Intergovernmental Fiscal Relations in the Russian Federation for 19992001.” However, this document has less buy-in and smaller scope than the Kozak Report. For a discussion, see Martinez-Vazquez (2002).
} 


\subsection{Sequencing}

Some would argue that the single most important factor in getting a successful decentralization in place is to include the key elements in the policy design. But what are the key elements? And, must all be introduced simultaneously, or are there some sequencing rules?

\section{3. $\quad$ Fiscal Decentralization Policy Should Be Comprehensive}

Intergovernmental fiscal relations must be thought of as a system, and all the pieces in this system must fit together (Bahl, 1999b). ${ }^{10}$ Ideally, the implementation of a decentralization program should begin with a design of the comprehensive system and should lay out the plan for each element of the system. Not all of the components of decentralization will be implemented right away, but it is important that all of the components be included in the comprehensive plan.

A little reflection will lead one quickly to the conclusion that fiscal decentralization involves more than what are traditionally thought of as fiscal issues. In fact, the electoral system and other forms of accountability, the civil service and a number of other institutional arrangements are arguably as important to assuring the success of fiscal decentralization as are the taxing and spending components. A "oneoff" piecemeal reform, encompassing only one element of the system (e.g., central government revenue sharing with local governments), is not likely to fully capture the benefits of decentralization. In fact, it can lead to undesirable outcomes, including larger central deficits and macroeconomic instability. ${ }^{11}$

The key elements to be included in the sequencing plan for fiscal decentralization are:

- expenditure assignment and autonomy

- revenue assignment and autonomy

- design of the intergovernmental transfer system

- provisions for fiscal discipline

- civil service rules

- political accountability

Getting all the pieces of the fiscal decentralization puzzle on the table gives the best chances for success. Making the pieces fit together is the sufficient condition. In a sense, this is what the sequencing question is all about. For example, Indonesia's bigbang decentralization of 2000 did consider both expenditure assignment and revenue assignment, but the planning was done by two different ministries with little coordination

\footnotetext{
${ }^{10}$ Intergovernmental fiscal relations is a term that refers generally to division of fiscal powers and responsibilities among levels of government. Fiscal decentralization refers to an intergovernmental system where the balance of power moves more toward the subnational government sector than has been the case.

${ }^{11}$ See Burki, Dillinger, and Perry (1999) for a discussion on these types of problems in Latin America.
} 
(Alm, Aten and Bahl, 2001). There did not seem to be a plan for making the two sides of the budget fit together.

Not everyone believes that design should be comprehensive. Some countries (and international agencies) may at times think of a fiscal decentralization program as no more than a revision of the existing revenue sharing system, or an upgrading of the property tax administration. ${ }^{12}$ Some ignore the fiscal issues completely and think of decentralization only in terms of the local election system, and planners very often focus exclusively on developing methods to get inputs from local population groups included in the project selection discussion. The "one dimension" approach is not likely to be sustainable or produce successful decentralization because other elements crucial to capturing the benefits may not have changed in a supportive way, or may even work to yield offsetting results.

\subsection{The Critical Role of Political Accountability}

Accountability to local voters is perhaps the most crucial element of a decentralized system, and the one that ties together all the other components of decentralization design. But is it the essential first step in the decentralization sequence? Local governments' expenditure and revenue autonomy are less likely to be put to good use (benefiting local citizens/voters) when local government officials are not accountable to their local constituencies. More centralized systems tend to substitute vertical accountability of local officials to higher up authorities for horizontal accountability to citizen/voters. Vertical accountability can prevent local officials from behaving irresponsibly but it works much less well in making them responsive to the needs and preferences of local residents. Horizontal accountability is enhanced through the appointment of officials through open politically contested elections, as well as by other institutions including, proper publicity, internal control and external audit and evaluation of budgets, a free press, and the participation in the public discourse of non-governmental organizations. The efficiency gains that are at the heart of fiscal decentralization strategies will not be captured if local voters cannot have a voice in making budget choices.

Countries like China, Vietnam and Nepal, which have been pursuing substantial decentralization reforms on many fronts, but which still do not have contested, democratic elections, are unlikely to benefit from the full range of efficiency gains associated with decentralization. In particular, the dominance of vertical accountability to upper-level government officials and the desire to please them quite likely leads to distorted spending decisions at the subnational level. ${ }^{13}$

\footnotetext{
${ }^{12}$ Of course, this may be quite correct if the issue is a correction being made to an ongoing system of fiscal decentralization.

${ }^{13}$ For example, Martinez-Vazquez, Qiao, and Wang (2005) argue that the lack of horizontal accountability in China has led to different expenditure patterns in poorer and richer provinces.
} 
Awareness of these issues has led both China and Vietnam to experiment with openly contested elections at the lowest level of local government, the rural settlements. ${ }^{14}$ A full solution to this problem will require a regime change, which is not likely to happen anytime soon.

Does the absence of elected local governments mean that decentralization in these countries is meaningless or ineffective? It would appear that there are still sizable advantages to be obtained from decentralization in production efficiency and competition among local governments, ${ }^{15}$ and some gains in allocative efficiency from limited levels of horizontal accountability. ${ }^{16}$

Full horizontal accountability to voters is limited in other developing and transition countries by less than full direct elections of executive and legislative branches of government. In a common modality, the legislative branch is democratically elected but the executive branch is appointed by the center, as will now be the case in Russia's regions. Representatives may be indirectly elected by lower-level governments, as in the case of the district councils in the Czech Republic. The point with any of these variations is that accountability and, therefore the overall performance of decentralization, will be hurt the further away the system moves from full democratic institutions. Even the method followed in democratic elections may have consequences for accountability. For example, proportional representation under closed-party list systems may generate strong alliances and accountability toward the party bosses in the capital of the country in comparison to the greater responsiveness to local issues in the case of district-wide winner-take-all open elections.

\subsection{Finance Should Follow Function}

It is important to get the correct order of reform as regards to how much should be spent by subnational governments, and how much revenue should be given to subnational governments. There is a conventional wisdom. First should come the assignment of expenditure responsibility to subnational governments, and then the assignment of revenue raising powers and central government revenue shares should be determined. There is a good logic to this finance-follows-function rule.

\footnotetext{
${ }^{14}$ See Bahl and Martinez-Vazquez (2005) for China and Martinez-Vazquez (2004) for Vietnam.

${ }^{15}$ Montinola, Qian, and Weingast, (1995) and Qian, and Weingast, (1996) argue that the fiscal decentralization process started in China in the mid-1980s with the "contracting system" was "market preserving" in that it stimulated local governments to become entrepreneurial and to seek the growth of their local economies.

${ }^{16}$ Local councils, although not freely elected, are often open to the complaints and demands of local residents. Furthermore, local governments in richer areas where there is more residential mobility, such as China's coastal provinces or in the Ho Chi Minh City area in South Vietnam, need to be more responsive to the preferences and demands of residents to retain and attract qualified workers and to compete for investors.
} 
The first reason is that one cannot establish the required level of subnational government revenues independent of an estimate of expenditure needs. ${ }^{17}$ The second reason is that it becomes difficult to effectively impose a hard budget constraint at the subnational level if there is an insufficient revenue assignment. Examples abound of local governments being given expenditure responsibilities and mandates that exceed their assigned revenues. Local governments may take this to mean that they are expected to overspend and that the deficit will be covered by the higher level government. If, on the other hand, subnational government revenues are over assigned relative to expenditure needs, then the central government can become fiscally strapped and there will be pressures on the central budget deficit. Such was the case in China in the mid1990s.

There is a third argument for finance to follow function, and this is discussed less often. The economically efficient assignment of revenues requires a prior knowledge of expenditure assignment. For example, services that may be priced (public utilities, bus transportation) should be largely financed by user charges; general services with a local area benefit zone (roads, parks) should be financed with local taxes; and goods characterized by significant externalities should be financed from region-wide taxes and intergovernmental transfers. A blanket statement that the aggregate of local government services should be financed by user charges, local taxes, and intergovernmental transfers, simply misses the efficiency point. Government must settle on the assignment of expenditure responsibilities to local governments, before it can choose an efficient mix of taxes (Bahl and Linn, 1992).

Despite all this good a priori reasoning, most countries begin intergovernmental reform on the revenue side. Examples of this sequencing mistake abound in Latin America. Currently, Thailand is in the midst of approaching policy in this fashion. And, there are some who would see this as a not-too-serious policy mistake. One justification for this "back-end" approach is that the expenditure needs of subnational governments often are so great that feasible intergovernmental revenue reform programs do not typically make much of a dent in the service level and infrastructure backlog. In such a case, it is sometimes argued that it matters little where one begins. This would seem a flawed argument, though. All that happens in this case is that standards for minimum subnational government services are increased or reduced in an implicit way. It is far better to do this reduction explicitly than implicitly. This argues for starting intergovernmental fiscal reform on the expenditure side.

Another reason why many countries get the revenue and expenditure assignment decision in the wrong order is that the revenue side is easier to work. Politically, at the central level, it is rather easy for a President to propose and a parliament to approve a proposition for a given percentage of central government revenues to be shared with local governments. This is a populist measure that not very many outside the government or

\footnotetext{
${ }^{17}$ Note that even if the subnational government revenue share is determined on a basis of expenditure needs, it does not follow that there will be a correspondence for every local government. The finance follows function rule applies only to the aggregate vertical share.
} 
inside the government, with the possible exception of the Ministry of Finance, will oppose. Political opposition is more likely to take place for issues involving the decentralization of expenditure responsibilities. From the perspective of local governments, an entitlement to some level of revenue sharing is clearly more attractive than being assigned expenditure responsibilities for which there may or may not be adequate funding. ${ }^{18}$

A positive argument for starting the process on the revenue side is that the assignment of revenue to local governments may dampen the resistance of line ministries to the expenditure reassignment that will follow. Once the funds to support certain functions have been transferred, there may be less of a rationale for line ministries to argue to keep control over direct delivery.

The assignment of expenditure responsibility is a much more politically charged issue. Giving local governments significant control over the expenditure budget reduces the control that can be exerted by the line ministries and shifts the balance of power away from the center. Moreover, once decentralized to local governments, expenditures are not so easily controlled or “called back.” Revenue assignment, as practiced in most developing countries, is a less permanent proposition: local tax rates can be limited or subject to approval, intergovernmental transfers to local governments might not be delivered as promised, and all borrowing might be subject to central government approval.

On the implementation side, policy analysts know well how to design reforms in tax systems and intergovernmental transfer systems, implementing these reforms is a manageable issue and such reforms can yield visible short-term results. The decentralization of expenditure responsibility poses more challenging implementation problems. First, the decentralization of expenditure responsibilities needs to be implemented in the context of reformed national sectoral laws (e.g. Education Law, Health Law, etc.). This will lead to redefinition of the role to be played by line ministries and other central government agencies within the new decentralized framework. The failure to coordinate central government sectoral policies with decentralization policy generally leads to confrontations between agencies at different levels of government, confusion in expenditure assignment, and inefficient outcomes. Second, subnational governments must have the capacity to deliver the newly assigned services or to develop the new skills to do so. The public policy fear is that service quality will deteriorate while local governments are climbing the learning curve.

Most bothersome of all, there are no hard and fast rules about which functions should be assigned to which level of government. Expenditure assignment decisions

\footnotetext{
${ }^{18}$ The exception is those countries where decentralization is driven by political, ethnic, or separatist reasons. In this case regional and local governments are eager to get as much expenditure responsibility as possible even if it is well known that the finances may not follow for some time to come. That is the position taken, for example, by ethnic republics in Russia, such as Tatarstan and Bashkortostan, or by the ethnic Indonesian provinces of Aceh and Papua-New Guinea.
} 
should be based on a painstaking unbundling of each function into sub functions, and for concurrent functions, the identification of attributes for regulation, financing and implementation, and then analysis of the viability of each as a central, state or local responsibility. ${ }^{19}$ Policy analysts, international donors, and central ministries all find reasons to shy away from this difficult analytic task.

Some analysts and even policy makers in countries undergoing recent decentralization take an "evolutionary" view of the expenditure assignment question. In this mind frame, the different levels of government will eventually sort out the functions they should perform. After all, it is claimed, one can find decentralized developed countries with rather stable and well sorted out expenditure assignments at different levels of government, which never had a comprehensive law that explicitly stated expenditure assignments. However, this argument ignores the fact that it may have taken these countries decades, if not centuries, of political friction and inefficient public sector operations to arrive at the de facto expenditure assignments one can observe today.

Is there a correct way to implement the finance-follows-function rule for sequencing? We suggest a three-step process. First, one might begin by clearly assigning a package of expenditure responsibilities to subnational governments on the basis of the subsidiarity principle, benefit areas of services and externalities present, economies of scale and scope, and best international practice. This is to some extent a subjective exercise, and there is no unique answer for every country. In fact, many countries apply these exact criteria and come to different answers about what subnational governments should do.

The second step is to establish the cost of providing minimum levels of these services. As in the case for expenditure assignment, there is no one best way to do this. The international practice suggests three basic approaches:

One can use a "retrospective" methodology and try to calculate a cost that is equivalent to the moneys spent on those services before they were decentralized (e.g., Spain). This approach simply assigns a vertical share of revenues to the subnational government sector that is adequate in amount to cover the existing level of spending for the functions being reassigned.

The advantage of this approach is that it is relatively easy to implement and minimizes disruption. The disadvantage is that it assumes that existing levels of spending are somehow "proper," when in fact it is these existing levels that may have prompted the move toward decentralization in the first place. If it is done on a region-by-region basis, it may perpetuate the service and funding inequities of the past. This approach is also problematic in a dynamic sense, for example if it is used to evaluate expenditure needs in equalization transfers formulae in future years, because the distribution of population and other conditions may change very fast.

\footnotetext{
${ }^{19}$ For a discussion of expenditure unbundling in the India context, see Sethi (2004).
} 
A second approach is to establish minimum spending levels by using per capita (or per client) financial norms. An advantage of this method is that the per capita financial norms can be modified by information on existing conditions in the local government areas, such as differences in prices due to climate or geography (e.g., South Africa, Ukraine, and the U.K.).

A more complicated approach is to define minimum physical service standards for the provision of each service and try to cost them out separately (e.g. Japan, the Netherlands, and Denmark). This approach has the advantage of allowing a costing of the inputs required for delivering a minimum level of services. Hence it can provide detailed information on the cost implications of higher or lower vertical shares.

The third step in this process is to bring affordability into the discussion. Ultimately, the choice of an exact minimum service level will be driven by affordability. While the retrospective method ensures affordability, the per capita method and the method that costs out and adds up physical norms and standards do not. ${ }^{20}$ What is affordable is also driven by national priorities. Thus, how a country ends up quantifying expenditure needs also depends on the national consensus regarding how important some services are vis-à-vis others, and in particular the importance of those assigned to the subnational sector vs. those retained at the central level. Some methods for quantifying expenditure needs, for example financial per capita expenditure norms, are more adaptable to changes in national priorities than others.

There is one last normative issue to be considered. This is whether expenditure assignments should be uniform for all subnational units. The alternative is some asymmetric treatment depending on administrative capacity and readiness of subnational governments to absorb expanded expenditure responsibilities. Asymmetric treatments have the disadvantage of creating complexity but the ability to adapt to very different conditions and capabilities may more than offset that disadvantage. Furthermore, asymmetric treatments are by nature temporary, because local governments have an incentive to use all the technical assistance provided so that they can graduate and assume the competencies assigned to their peers.

The arguments for finance to follow function do not seem to have fully persuaded international practice, as described in Table 1.

\footnotetext{
${ }^{20}$ We should note that the problem of quantifying needs is not unique to expenditure assignments. Equalization transfer systems that take into account needs also are presented with the same exact problem.
} 
Table 1: Summary of Selected Decentralization Sequencing Issues in Five Case Countries

\begin{tabular}{|c|c|c|c|c|c|}
\hline & Indonesia & Russia & India & Tanzania & Mexico \\
\hline $\begin{array}{l}\text { Rationale for Fiscal } \\
\text { Decentralization }\end{array}$ & $\begin{array}{l}\text { Over centralization in } \\
\text { decision making; secession } \\
\text { threats }\end{array}$ & $\begin{array}{l}\text { Secession threats; } \\
\text { demand for local } \\
\text { political autonomy }\end{array}$ & $\begin{array}{l}\text { Need to establish fiscal } \\
\text { discipline at the state } \\
\text { level; demand for } \\
\text { decentralization to third } \\
\text { tier. }\end{array}$ & $\begin{array}{l}\text { Improve quality of } \\
\text { local service delivery } \\
\text { by giving more fiscal } \\
\text { discretion to local } \\
\text { governments. }\end{array}$ & $\begin{array}{l}\text { Reaction against over- } \\
\text { centralization and demand } \\
\text { for greater local political } \\
\text { autonomy. }\end{array}$ \\
\hline $\begin{array}{l}\text { Finance Follows } \\
\text { Function }\end{array}$ & $\begin{array}{l}\text { Revenue assignment and } \\
\text { transfers, and expenditure } \\
\text { assignment were developed } \\
\text { simultaneously by two } \\
\text { different ministries }\end{array}$ & $\begin{array}{l}\text { Murky expenditure } \\
\text { assignments that have } \\
\text { changed over time. }\end{array}$ & $\begin{array}{l}\text { Revenue assignment } \\
\text { and transfers change } \\
\text { over time by Finance } \\
\text { and Planning } \\
\text { Commission } \\
\text { recommendations. } \\
\text { Expenditure } \\
\text { assignments, with a } \\
\text { long “concurrent” list } \\
\text { are based on the } 1950 \\
\text { Constitution. }\end{array}$ & $\begin{array}{l}\text { Followed the "finance } \\
\text { follows function" rule } \\
\text { but with some } \\
\text { murkiness in } \\
\text { expenditure } \\
\text { assignment. }\end{array}$ & $\begin{array}{l}\text { Expenditure assignments } \\
\text { are defined by sectoral } \\
\text { laws. }\end{array}$ \\
\hline $\begin{array}{l}\text { Subnational } \\
\text { Government } \\
\text { Taxing Powers }\end{array}$ & $\begin{array}{l}\text { Minimal local government } \\
\text { taxing power }\end{array}$ & $\begin{array}{l}\text { Minimal regional and } \\
\text { local government taxing } \\
\text { power }\end{array}$ & $\begin{array}{l}\text { States have some } \\
\text { significant taxing } \\
\text { powers. Local } \\
\text { governments have } \\
\text { access to property tax } \\
\text { and little else. }\end{array}$ & $\begin{array}{l}\text { Minimal local taxing } \\
\text { power }\end{array}$ & $\begin{array}{l}\text { States raise about } 5 \\
\text { percent of revenues from } \\
\text { own taxes. Municipalities } \\
\text { raise about one-third of } \\
\text { revenues from own } \\
\text { sources. }\end{array}$ \\
\hline $\begin{array}{l}\text { Rationality in the } \\
\text { design of the } \\
\text { transfer system }\end{array}$ & $\begin{array}{l}\text { Core grant is unconditional } \\
\text { and vertical sharing rule is } \\
\text { transparent. Natural } \\
\text { resource revenue sharing } \\
\text { has less clear objectives and } \\
\text { exacerbates disparities. }\end{array}$ & $\begin{array}{l}\text { A formula-based } \\
\text { equalization grant has } \\
\text { been established. } \\
\text { Revenue sharing is not } \\
\text { equalizing and } \\
\text { conditional grants not } \\
\text { well developed. }\end{array}$ & $\begin{array}{l}\text { Transfers are distributed } \\
\text { by three different bodies } \\
\text { with what often appear } \\
\text { to be contradictory } \\
\text { objectives. }\end{array}$ & $\begin{array}{l}\text { All grants are } \\
\text { earmarked and both } \\
\text { vertical and horizontal } \\
\text { shares are distributed } \\
\text { in an ad hoc way. } \\
\text { There is no } \\
\text { equalization grant. }\end{array}$ & $\begin{array}{l}\text { Transfers are distributed } \\
\text { by formula but the overall } \\
\text { results are not equalizing. }\end{array}$ \\
\hline $\begin{array}{l}\text { Policy Paper or } \\
\text { White Paper }\end{array}$ & $\begin{array}{l}\text { There was no policy } \\
\text { framework. }\end{array}$ & $\begin{array}{l}\text { A White Paper was } \\
\text { developed after the } \\
\text { decentralization } \\
\text { program was underway. }\end{array}$ & $\begin{array}{l}\text { The Federal Finance } \\
\text { Commission reports } \\
\text { every five years. The } \\
\text { State Finance } \\
\text { Commissions report } \\
\text { every three years. }\end{array}$ & $\begin{array}{l}\text { A White Paper guides } \\
\text { decentralization policy } \\
\text { development. }\end{array}$ & \\
\hline
\end{tabular}




\subsection{The Significance of Local Revenue Autonomy}

It is important to a complete decentralization that subnational governments have independent sources of revenue. If all financing is from revenue sharing and other forms of transfers from higher-level governments, there is a danger of the lower level government becoming a spending agent for the center. Such an arrangement can give subnational governments less discretion in deciding how much they will spend, and how they will spend it in the case of conditional grants. The imposition of a hard budget constraint is more difficult when there is no local revenue raising capability. Once a culture of dependency on revenue sharing and transfers is created, subnational governments will always push for more funding from above as opposed to using their own revenue autonomy. As the international experience shows, many central/federal governments eventually succumb to demands and pressures from below for more revenue sharing, and the pattern continues.

There are several important beneficial effects of subnational government revenue autonomy that are often overlooked. First, subnational tax autonomy is the best way, if not the only way, to address permanently the problem of vertical imbalances in fiscal decentralization design. Second, there cannot be discretion as regards to the level of expenditure and a hard budget constraint on subnational governments unless at the margin they are required to use their own revenue instruments to raise additional revenues. Third, revenue autonomy is a key indicator of subnational governments' borrowing capacity and creditworthiness. All of this argues for revenue raising to be an early decision in the design of a fiscal decentralization strategy.

In practice, local revenue sources are often not part of the initial decentralization package. To some extent, this is because there is no constituency for this policy. Central government officials do not want to devolve taxing powers for fear of competing with local governments for the same taxing base. Subnational government officials are loathe to take on the responsibility of making politically unpopular taxing decisions to meet budget needs. Moreover, some local officials may fear that new local taxing powers may be accompanied by a more equalizing distribution of intergovernmental transfers that would penalize their increased tax effort. Intergovernmental transfers are seen to be a much easier path for all concerned.

Of the five country cases highlighted here, Indonesia, Russia and Tanzania provide subnational governments with little discretion to raise tax revenues. Mexican municipal governments cover about one-third of expenditures from their own sources but state governments are mostly dependent on transfers. India's states do have significant taxing powers but urban and rural governments are mostly limited to the property tax. A more detailed discussion of subnational government revenue raising power is summarized in Table 1. 


\subsection{Design of the Intergovernmental Transfer System}

An important sequencing question has to do with the design and implementation of intergovernmental transfers. The right order of policy formulation is to first ask and answer the question about which of many possible objectives the intergovernmental transfer system is to accomplish, and then to design the reformed system.

There are many different kinds of intergovernmental transfer systems, and they have many different types of impacts on local government finances. ${ }^{21}$ Some stimulate local spending, some are substituted for local revenue effort, some are equalizing, and some lead to more local government fiscal autonomy than others. ${ }^{22}$ Countries too often enter into the process of grant design without clear objectives for what the transfer system is to accomplish.

The major issue is that different types of transfers have different objectives, and it is important to sequence grant design according to these objectives. One goal is to reconcile the difference between the assignment of expenditure responsibility and the assignment of revenue raising powers. This vertical balance goal of transfers is arguably the first job to take care of in designing the transfer system. The second step in grant system design is to implement conditional grants for those functions of national/regional importance where it is feared that under-provision might take place without assistance. Finally, the equalization grants should be designed to address the horizontal imbalances that result after the first two pieces of the transfer system are designed.

Often, countries do not design their intergovernmental transfer systems in so rational a way, as can be seen for the five countries highlighted in this study in Table 1 .

\subsection{Subnational Governments Must Face a Hard Budget Constraint ${ }^{23}$}

Fiscal discipline is a key element of a successful decentralization strategy. It is important that it be introduced when the program begins. If subnational governments are not forced to operate with balanced budgets, they become accustomed to looking to the higher level governments to cover their shortfalls. The moral hazard here is that the subnational governments will consciously overspend knowing that their losses will be made good. Furthermore, a soft budget constraint will tend to discourage their own tax effort and encourage inefficient and even wasteful spending. As many countries have learned, it is difficult to break the culture of a soft budget constraint.

\footnotetext{
${ }^{21}$ There is often a debate about what is an "intergovernmental transfer." Grants to lower-level governments are clearly intergovernmental transfers. The confusion comes in the case of shared taxes and tax expenditures. We would argue the following: If the local government can control either the rate or base of a levy, it is a tax. If the rate and base are determined by the higher-level government, and revenue collections are assigned to the local government, it is a transfer. If the central government allows deductibility of property taxes from central income tax liability, it is likewise a form of transfer.

${ }^{22}$ For a primer on transfer design issues see Bahl, Boex, and Martinez-Vazquez (2001).

${ }^{23}$ See Rodden, Eskeland, and Litvack (2003).
} 
A hard budget constraint implies that those local governments who are given autonomy will be asked to balance their budgets without recourse to any end-of-year assistance from the central government. Central governments must enforce this rule, and local governments must believe that they are "on their own." For a hard budget constraint to be an effective feature of intergovernmental fiscal policy, the higher level government should be mostly committed to a "no-bailout strategy" and to shy away from year-end deficit grants. A hard budget constraint is not always a central tenet of decentralization. Many central governments prefer to hold to a paternalistic approach to intergovernmental fiscal relations characterized by insufficient formal revenue assignments, fuzzy ex-ante levels of transfers, and year-end results covered by some sort of deficit grants. In other cases, there may simply be a flawed design of the intergovernmental fiscal system. Brazil's states did not face a hard budget constraint and increased current expenditures in the 1990s even when the resources were not available to cover debt repayment. Ultimately, there was a federal bailout.

The experience in the country cases studied here has varied. Indonesia does impose a hard budget constraint on local governments. Two factors are important in assuring this fiscal balance: there are few avenues open to local governments to finance a deficit, and the primary intergovernmental transfer was set at a level sufficient to cover personnel costs. India, on the other hand, is at the opposite extreme with state governments running deficits of significant size. The Union government has adopted numerous policies that encourage this behavior.

Mexico and Russia are somewhere in between. After a period of allowing a soft constraint on regional government budgets (through loan forgiveness and year-end "mutual settlements"), Russia has moved to adoption of a hard budget constraint for subnational governments. Mexico has a history of bailouts and of fearing the fiscal failure of important subnational governments, hence its threat of imposing a hard budget constraint for the future may lack credibility.

\subsection{The Decentralization Law}

It is essential that legislation govern decentralization, and that it is unambiguous. It would seem almost axiomatic that the development of the decentralization law should follow the policy design. Otherwise, how could it reflect the goals of government and the consensus resulting from the national debate?

There is much to be said about defining the best legal framework for decentralization. A fundamental question would seem to be how much of the decentralization framework should be in the constitution and how much should be in the decentralization law. This is a crucial sequencing decision, though for countries with longstanding traditions of decentralization, this question may have long ago been resolved. What shape decentralization takes in federal systems is fundamental to the very nature of the state and therefore the division of powers and responsibilities among the federal and subnational governments is an intrinsic part of the constitution in these countries. This is, for example, the case of three federal countries considered here: India, Mexico and Russia. 
How much detail there is in the constitution about intergovernmental relations and how much is structured in separate laws varies from country to country. India's Constitution is much more detailed about how fiscal relations (expenditure and revenue assignments and so on) should be structured than are the Constitutions of Russia and Mexico. In the case of Russia, two fundamental codified laws (the Budget Code and the Tax Code) now represent the legal backbone of the decentralization system. In the case of Mexico, the most important pieces of decentralization have been built by specialized laws either on the financing side (e.g., the National System of Fiscal Coordination law) or the expenditure side (e.g., the Education law) of the budget.

Although all power resides with the central government in unitary states, it is not uncommon in the constitutions of these countries (e.g., Indonesia and Tanzania) not only to acknowledge the existence of subnational governments but also to address some of the fundamental issues on how intergovernmental relations should be organized. Typically, this is done with much less detail and concreteness than in the case of federal country constitutions. In the case of unitary countries, it is more common to find specialized laws focused exclusively on fiscal decentralization issues. Indonesia's Law 22 on expenditure assignments and Law 25 on revenue assignments and transfers are cases in point. Although Tanzania's constitution makes reference to the role of local governments, the (fiscal) powers of local governments in Tanzania emanate primarily from the Local Government Acts (1982). ${ }^{24}$

Whatever the country's legal tradition, the essential goal is to have explicit and clear legal rules governing decentralization. It is often argued that these rules should always be part of the country's Constitution. This position is taken by those that fear the discretionary and potentially abusive exercise of power by the central government. Having these rules in the constitution is a measure of protection for local governments' interest, probably a protection that is as good as it gets. Changing the country's constitution requires jumping through many more hoops, but it can be done and it has been done. On the other hand, there also are some drawbacks to using the Constitution as the vehicle for structuring intergovernmental relations. An important one is the lack of flexibility and adaptation to changing needs and circumstances. If one views the intergovernmental fiscal relations as a continuous changing reality and sees a need for the legal system to adapt to this changing reality, then the role of the Constitution should be just to announce general principles and leave the details to laws and regulations. ${ }^{25}$ In fact, this is an important sequencing decision.

\footnotetext{
${ }^{24}$ The biggest problem in Tanzania in this regard has been that rather than replacing the previous legislation and regulations, the existing legislation tends to be amended with additional clauses. Over two decades of incremental reform, this has led to numerous instances of unnecessary duplicative clauses. As a result, a major review and "cleaning up" of the Local Government (Finance) Act will be needed in the near future.

${ }^{25}$ The constitution can be effectively used to state general principles of tax assignments and other aspects of decentralization. One example is the prohibition of border taxes or similar levies that impede commerce and trade between subnational jurisdictions, as is the case, for example, with the "commerce clause" in the United States Constitution.
} 
India illustrates some of the perils of putting too much detail about intergovernmental fiscal relations in the Constitution. In particular, the decision to specify revenue assignments between the Union and the states in the Constitution has resulted in inflexible and outmoded revenue structure for India. The Indian Constitution assigns to the states, among others, the tax on the sale and purchase of goods (but not services) and tax on agricultural incomes and wealth (but not incomes from other sectors). ${ }^{26}$ Any tax residuary powers are vested with the central government. This has led to the paradoxical situation that the sales (and purchases) of goods are taxed at the state level, the sales of services can only be taxed at the federal level. ${ }^{27}$ Allowing state governments to tax services would require a constitutional amendment. This situation has made it very difficult to reform indirect taxation in India, i.e., to introduce a VAT at the state and federal levels. Similarly, because the states can only tax income from agriculture, this has ruled out an income tax or piggyback income tax at the state level. Again, introducing this type of reform will require a constitutional amendment.

Similar problems arose in Brazil. The 1998 Constitution gave state governments significant tax authority and guaranteed transfers, but it did little by way of specifying expenditure responsibilities for the states (Rodden, 215). The result was confusion over responsibility for service provision. On the other hand, the constitution restricted the right of states to dismiss public employees or reduce their salaries. This significantly compromised the position of the states in regards to control over their budgets.

Whatever the approach chosen, relying more on the Constitution or more on other laws, it is clear that no legal documents can be as complete as to eliminate all possible ambiguities or differences in interpretation of the same legal text by two parties with potentially conflicting interests. Therefore, as the old wisdom goes, there is no system of federalism — and we will add, or of a decentralized system — that is complete without an independent and strong judiciary.

\subsection{Implementing Regulations}

The implementing regulations must fit between the development of the Law and the actual implementation of the system. Without the law, the regulations become decentralization policy, a most undesirable state of affairs. If there are no regulations, those who put the decentralization programs in action are free to do so as they wish.

\footnotetext{
${ }^{26}$ Other items in the closed list of taxes assigned to the states include stamp duties on registration fees, excise duties on the sales of alcoholic products, tax on motor vehicles, and tax on goods and passengers transported through roads and inland waterways.

${ }^{27}$ The division of tax bases between the union and state governments appears to be quite arbitrary from today's perspective although for sure there were some reasons that would have seemed relevant to the framers of the Constitution many decades back. This illustrates the point that the constitution is a more inflexible legal vehicle for structuring intergovernmental fiscal relations.
} 
The implementing regulations specify the detail for the roll out of the decentralization program. Like the law, these regulations follow the policy framework by providing the detail that governs the administration of the new system. Unlike the law, the implementing regulations can be easily changed. The major issue that arises is what should be included in the law and what should be included in the implementing regulations. The international practice varies with the legal traditions of countries. For example, Russia's tradition of codified laws follows the continental legal tradition of incorporating in the law more detail and interpretation than is the case in the common law tradition. In Indonesia, laws contain very little detail because traditionally the country has relied on the implementing regulations to structure many important aspects of a reform.

What is the right division of content between laws and regulations? The Law should include those things that Government feels are to be relatively permanent in decentralization policy. For example, provisions for the election of local officials, basic expenditure and revenue assignments, the fundamental structure of the equalization grant, or the civil service status of local and central government employees are not likely to change over time-or at least should not change frequently_and properly belong in the law. Other factors, such as the weighting parameters in the intergovernmental transfer formula or provisions for revenue sharing rates or administration arrangements, may change with economic development and other changing circumstances and probably belong with the implementing regulations rather than the law.

Getting the implementing regulations out of sequence can be quite disruptive of the decentralization program. If these are written before the policy paper is completed, then the regulations themselves become an important part of the decentralization policy. This is part of a "make it up as you go" approach. The implementing regulations in this case would be written by different government ministries following more or less their own preferences and the different pieces are unlikely to fit any unified strategy.

On the other hand, if the implementing regulations are not written before the start of the implementation period, then it is left to those who administer the new program to decide on the elements of the decentralization. For example, if the exact assignment of functions is not made clear, then it may be left to the subnational governments to decide what they will and will not deliver, or to the central government line ministries to decide how much control they will relinquish.

\section{Implementation}

Implementation of a decentralization program involves more than simply a passing of administrative responsibilities to lower levels of government. It involves developing a strategy for implementation and a significant amount of planning and fails safe provisions to accommodate failures in the early stages of decentralization. This planning is part of the design phase of the sequencing. Actual implementation comes after the implementing regulations are complete. 


\subsection{Transition Measures: Asymmetric Decentralization}

The transfer of fiscal powers to local governments may or may not involve a oneoff delegation of the same authority to every local government. Governments in many countries believe that there must be a uniform intergovernmental fiscal system under which all subnational governments must operate. Certainly there are good arguments for this. If all subnational governments have the same expenditure responsibilities and revenue raising powers, management of the system and evaluation of its success is much easier. Moreover, there is no hint of political favoritism as ad hoc differentiation among local units is not permitted. Uniform symmetrical systems seem fairer. By design, Tanzania's system of local government finance is perfectly symmetric.

There is another view, that uniformity may not be a necessary condition for effective decentralization. In fact, a better route may be to begin fiscal decentralization with the larger local government units and to let the smaller ones "grow into it." Subnational governments have very different capabilities to deliver and finance services, and certainly different capabilities to borrow. It may be necessary to set up a system where these differences are explicitly recognized, i.e., where different local governments are given different financing powers and expenditure responsibilities. Places with limited capability could rely more heavily on grants and perhaps have less expenditure responsibilities, while local governments with greater administrative capacity or more developed places in general could rely more heavily on local taxation and could borrow to finance capital outlays. In countries that choose this route, it is necessary to have a clear set of rules about when a local government graduates from one status to another, and to have systems in place for training, and so on, that allow local governments to graduate faster if they so desire. It is not at all uncommon to see such gradations, e.g., the Kenyan municipalities and cities, large cities in some American states, South African municipalities and cities, Indian urban governments, and many national capital districts are given special fiscal powers. ${ }^{28}$ Countries like Spain and Colombia have successfully used asymmetric approaches in the decentralization of expenditure responsibilities.

Asymmetric approaches to revenue and expenditure assignments are used sometimes in response to either special political demands or try and satisfy separatist forces. At some point during the transition, the Russian federal government had secret treaties providing asymmetric status to a number of Russian regions to accommodate all sorts of demands. More uniform treatment of all the regions in Russia have followed after years of recentralization and hard discipline introduced by President Putin (MartinezVazquez, 2002). Many other decentralized countries (e.g., Canada, Spain, etc.) function with different forms, at times quite radical, of asymmetric federalism (see Bird and Ebel, forthcoming). But even in systems where asymmetry is involved, there are certain common features that tie all local governments together. There should be one law common to all local governments in the system and one uniform set of accounting and auditing rules.

\footnotetext{
${ }^{28}$ It is very difficult to identify a set of characteristics that prescribe when a local government should move to the next class of fiscal autonomy. Most countries use population size as the classification criteria.
} 


\subsection{Building Capacity}

Perhaps the biggest constraint to the implementation of a decentralized system of government is the lack of administrative capacity by local governments. When decentralization takes place and the administrative capacity is not in place, what may follow is poor performance in service delivery with all sorts of inefficiencies, waste, corruption, and lack of accountability. Systemic failure of local governments to deliver services is in the long term the worst enemy of decentralized governance. Sooner or later the solution found will be to recentralize the public finances. ${ }^{29}$

The lack of local government capacity is often used to justify tepid decentralization or no decentralization at all. This is the most common reason given in "half-baked" decentralization processes, such as in India or Mexico, where decentralization has stopped at the intermediate level of government and has not reached third-tier local governments in a meaningful way. Full decentralization reform to local governments has been stalled in Tanzania because of the alleged lack of capacity among most local governments. At the other extreme, the big bang decentralization reform in Indonesia was carefree about the lack of capacity among many local governments and fully decentralized to local governments while bypassing the intermediate (provincial) level of government. The reform was uniform and there was little accommodation for lack of capacity at the local level. The risks were minimized, however, because a deconcentration system of service delivery was already in place.

In many ways the issue of lack of capacity at the local government level is a "chicken and the egg" dilemma. Decentralization may not take place because of the lack of capacity but capacity has never developed because there never has been any meaningful degree of decentralization. The right approach to this issue is a pro-active policy that combines capacity training and asymmetric measures with progressive devolution of responsibilities and financing instruments. It does not make much sense to wait for decades, like in India, for the capacity to appear at the local level. At such a pace local governments may never be ready. But the need for resources and a strategy may not be the main obstacle to developing capacity at the local level; rather, the problem may be entirely political. This is true because intermediate level governments, even though they may demand as much decentralization as possible from their central governments, often like to act as highly centralized mini states vis-à-vis their local governments.

\footnotetext{
${ }^{29}$ Political memories tend to be short and it may not matter much that service delivery was not better under a previous centralized approach.
} 


\subsection{Contingency Funds}

Like most other government policies, decentralization policy is designed and implemented with limited information and therefore there is always the risk that things may not come out as expected. For this reason, it is important to provide the implementation process with contingency funds to cover unforeseen circumstances. When Indonesia embarked on its big bang decentralization the Government arranged for several contingency funds to help with the finances of those local governments that may have run short of funds to pay employee salaries and the like.

\section{Big Bang or Gradual Implementation?}

A gradual implementation of reform is thought by many to be more desirable than a hurried up, "big bang" approach. There are two good reasons why this might be preferred: (a) limited available information to allow good predictions on how things will eventually work out, in contrast to how they were planned, and (b) the cost of reform can be substantial, and gradual approaches allow this to be spread out over a number of years. In short, gradual approaches carry much less risk.

To argue for the proper sequencing of reform as we do in this paper is probably to argue in favor of gradualism in its implementation. The question is what form of gradualism is best. Systems that are politically centralized, like China today, may have the luxury of trying out pilot reforms to check for problems and "wrinkles" before rolling out the reforms for the entire country. But piloting and experiments are not always possible and may not even be desirable if there is urgency to the problems that need to be addressed. Gradualism may also be understood in the context of asymmetric approaches to decentralization. For example, the Spanish Constitution in the post-Franco era allowed for several speeds of decentralization reform, to a large extent based on historical autonomic demands of a handful or regions vis-à-vis the rest of the country. Decentralization reform in that country was spread over several decades, but some regions got on with the reforms much faster than others. ${ }^{30}$ In Colombia, the asymmetric approach and differences in speed of implementation were based more on administrative capacity reasons than on historical reasons. In short, even though there are different interpretations of gradualism, many of them acceptable in their particular country context, we believe that the best interpretation of gradualism is the paced implementation of the sequencing being presented in this paper.

But two important qualifications should be added to that statement. First, we must not see the type of gradualism being proposed here as a substitute for a comprehensive blue print for decentralization reform. This confusion has often been found in the general debate in the economics literature over the proper pace of economic policy reform. ${ }^{31}$ As

\footnotetext{
${ }^{30}$ At present all regions in Spain have reached the same level of decentralization but asymmetries persist, especially in revenue assignments, with special privileges for the Basque Country and Navarre, because of constitutional design based on the interpretation of separate historical traditions.

${ }^{31}$ For example, McMillan (2004) recently argues for a step-by step approach to (general) economic reform but identifies this approach with the absence of any comprehensive blueprint.
} 
already stated several times throughout this paper, in our view a gradual implementation approach should always be based on an explicit plan with goals and the institutional changes necessary to get there.

A second qualification in regards to the superiority of a gradual approach is that policy makers usually do not have the opportunity to reform in a gradual fashion. It is well accepted that timing is critical in policy success. For example, an economic crisis and political transition from an authoritarian and highly centralized regime may provide a very limited window of opportunity to advance reforms that, it may be believed, under other circumstances may be very hard or even impossible to introduce. Going for a big bang approach to decentralization reform in these circumstances can be a measured and acceptable risk. That was the situation in Indonesia after the resignation of President Suharto in 1998. With several years now passed, Indonesia's big bang reform appears to have been successful. ${ }^{32}$ Perhaps one can look to other transitional countries that implemented very rapid decentralization reforms accompanied by other general economic reforms, such as Estonia and Poland, where the big bang approach has worked.

None of the other countries of reference in this study implemented a big bang approach, ${ }^{33}$ not even Russia, which in some circles has been often interpreted as an example of failure of the big bang approach to general economic reform. The evidence from other developing countries is that a big bang approach can fail to deliver. For example, Giugale et al. (2000) point out that the Latin American experience with decentralization shows that big bang, abrupt reform efforts in countries such as Brazil, Colombia, Bolivia and Venezuela during the 1980s and 1990s generally failed.

\section{Transition Measures: Hold Harmless versus "Cold Turkey”}

Many forms of fiscal decentralization reform imply that there will be winners and losers among the subnational governments. Sometimes, politically and/or economically powerful subnational governments may effectively veto the reform unless their concerns about the losers under the new system are taken into account. For example, the powerful tax rebate system introduced in China to compensate the rich coastal provinces for the other effects of the 1994 reform can be interpreted in this light. More often, a particularly difficult issue arises when the system of distributing intergovernmental transfers among local governments is dramatically changed, as for example from a negotiated system to a formula-based system. This change will almost certainly produce local governments who make big gains from the new formula transfers, and others who face big revenue losses. Usually, the local government service delivery system, and the local political system, cannot withstand large one-time shocks without causing turmoil in the delivery

\footnotetext{
32 The Indonesia approach included some safeguards such as the provision (which apparently was never used) that provinces would assume responsibility for service delivery if local governments were unable to do so.

${ }^{33}$ India can be interpreted as a paramount example of gradualism in reform, and one that also illustrates well that gradualism per se does not deliver success either.
} 
of essential services. In these cases, some form of phase-in of the new system is called for.

Indonesia's big bang decentralization called for a switch from an infrastructure grant program, and a grant program designed to finance the compensation of government employees working at the local level, to a formula- based unconditional grant program. The "entitlements" under the old system had built up over time, and it was exactly these inequities that the new system was designed to eliminate. Nevertheless, a significant shock would have resulted had the new formula system been introduced in one fiscal year. Instead, the decision was made to phase in the new system, and in the early years, to hold all "losing" local governments harmless at their pre-reform levels. The mistake in the Indonesian transition was that the period it would take to phase in the new formula was left unspecified, leaving the door open for politicians to use hold harmless provisions to advantage their constituent local governments. ${ }^{34}$ The result was a longer phase-in period than might have been desired.

Tanzania is also moving to a formula grant from a system where the distributions to local governments were negotiated. The same situation exists as in Indonesia: there is no reason to expect that any fair formula for supporting health and education finance will bear any relationship to the previous negotiated distribution. There would be winners and losers. As big a concern was the possibility that winners might include previously underfunded local authorities who would not have the capability of efficiently handling a large windfall gain in revenues. The government has decided to use a hold harmless approach and to phase in the new grant program over a period of years. Although the transfer system currently holds local governments harmless against their previous year's transfer levels, one year into the program, the exact transition period has not yet been defined. However, the Government is in the process of deciding on a deadline for phasing out the hold harmless provision. ${ }^{35}$

But not all countries provide for a formal hold harmless transition system. When no formal transition system exists, it does not mean that there is not an informal one. For example, the introduction in Russia of a formula-driven system in substitution for negotiated ad hoc transfers did not provide for a formal transition mechanism. But the federal government continued to use "mutual settlement” transfers as the means to cushion the impact of the changes. On top of that, the Duma or parliament intervened and changed the actual allocations of the formula-driven transfer to fit what it thought was the

\footnotetext{
${ }^{34}$ Part of the concern by Parliament for phasing in the transition to a new transfer system is that the loser local governments may not have had enough funds to pay the salaries of their employees (many of whom recently had been shifted down from the central government payrolls.) As already pointed out above, the current policy is to go back to direct transfers for employee salaries and discharge the equalization grant from the hold harmless provision, which has limited its effectiveness for the last three years.

${ }^{35}$ Several problems are preventing the Government from phasing out the hold-harmless provisions sooner rather than later. First, the Public Service Act/Regulations technically still allows central ministries to appoint teachers at the local level. As long as this is the case, local governments have to be held harmless for decisions they have no control over. Second, with elections at the end of this year, politically this is not seen as a good time to announce the phasing out.
} 
"just” allocation for four years until a new formula was introduced in 1998. South Africa, on the other hand, defined and implemented a four year phase in period for its formula-based equitable shares grant to local governments.

In other cases there is no need for hold-harmless provisions because most of the reforms are done in a gradual fashion anyway without any large changes in the distribution of transfers. This has been the case of India, with its gradual reforms of intergovernmental transfers, implemented over a period of sixty years. Other countries may make a hold harmless provision unnecessary because the change is implemented in such as way that there are no net losers or because the change is made voluntary. This latter illustrates the path followed by Canada and Mexico to the reforms of the revenue assignments over the last three decades.

\section{Monitoring and Evaluation}

Many developing and transitional countries may be characterized as very centralized systems of government and are likely to remain centralized for quite some time. A plausible scenario in such countries is that fiscal decentralization will be to a large degree controlled and regulated from the center.

In some cases the control will reflect hesitancy on the part of the higher-level government to give powers to a new group of bureaucrats. But in other cases, regulation and oversight can be seen as a needed feature of the fiscal decentralization structure. The following are some examples of the latter:

As subnational governments move toward debt financing of capital improvements, central governments will be called on to establish disclosure requirement and enforce borrowing limits. The center must monitor the fiscal performance of local governments, and identify those in financial difficulties as well as those exerting weak revenue mobilization efforts. The success of central government finance instruments (transfers, subsidies, local taxes) should be monitored annually and fine-tuned periodically.

Compliance with the terms of conditional grants, expenditure mandates and taxing limits need to be confirmed by the center. There is need for the center to provide technical assistance to local governments in several areas. Especially the smaller local governments require assistance in areas such as accounting, treasury, tax administration, data processing, and project evaluation.

Typically, central and state governments in most developing and transition countries are not up to the task of monitoring and evaluating local governments. The two ingredients necessary to this job are (a) a fiscal analysis unit, probably best located in the Ministry of Finance, with staff adequate to continuously monitor local government finances, and (b) an extensive data system that will allow quantitative monitoring and evaluation. 
A key underlying requirement for successful fiscal decentralization is a uniform structure of subnational government accounts that are regularly and properly audited. There are problems with the availability of such a comprehensive data system in most developing countries. A census of government finances, reporting the actual financial outcomes for every subnational government, is essential information if the performance of the intergovernmental system is to be monitored. Yet, it is not common in developing countries to have an up-to-date information system that describes the finances of subnational governments in detail. Rarer yet is a fiscal analysis model that is used to track the performance of local government finances (Bahl, 1999b).

\section{Breaches in Sequencing: Causes and Risks}

The primary question we raise in this paper is whether sequencing matters in developing and implementing a fiscal decentralization policy. Our answer is that it does, and that mistakes in sequencing can lead to significant resource costs and possibly to a loss in confidence in the decentralization initiative.

We also raise two secondary questions in this paper. First, we ask whether there is something akin to an optimal sequencing for decentralization policies and implementation. Our answer is that there is, and that following these sequencing rules might minimize the costs and the risks of implementing fiscal decentralization. Second, we ask about the extent to which countries follow these optimal sequencing rules. The answer would appear to be that in general, they do not.

What to make of this gap between theory and practice? One might consider a couple of conjectures. First, sequencing does not matter. Second, there is a lack of information or there are institutional and political constraints. In this section, we address in more depth these two possibilities.

\subsection{Sequencing Does Not Matter?}

One might argue that the order of introducing decentralization policy does not matter, that sooner or later the structure of decentralization in a country will end up at the same place no matter how one goes about it. Look for example at the U.S., as strong an example of working fiscal decentralization as there is. There was probably never a comprehensive "white paper" on state and local government finance, yet the system grew up to be quite functional. De facto, this is exactly the stance on sequencing decentralization policies that seems to have been taken in many developing countries.

The question is whether this is a wise strategy for developing countries, most of which are in the early stages of decentralization. Certainly one can understand the appeal. Decentralization policy is after all a political decision, and the design and implementation of such a program will be driven by bargaining and political timing. Even so, we would argue against the "make it up as you go" strategy, for the following reasons: 
First, it does not give the country leaders a chance to develop an end strategy for decentralization, that is, it does not let them design a program that will eventually achieve the objectives of the decentralization. If the strategy is made up annually to respond to current problems, the decentralization is not likely to end up as it would if a designed strategy were followed. Is this a bad thing? One might argue that even if there were a framework, it could be changed over time by new political leadership. Moreover, a program that responds to current problems might not be a bad strategy, i.e., oil the wheel that squeaks.

A problem with this approach is that it invites the prospects of being driven exclusively by politics. Absent a policy frame, self-interested groups might make amendments to specific policies that are not consistent with the other pieces of the program that are already in place. The danger is that over time, a system can lose focus.

An example of this danger is the Indian system of intergovernmental transfers. Over time, the Finance Commission has concentrated primarily on equalization transfers and on supporting a proper vertical share. The Planning Commission has focused on capital grants, and mixed loan and grant programs. The line Ministries have operated a plethora of conditional grants, whose purposes and impacts are by now largely unknown. Few would argue that the Indian system of intergovernmental transfers has ended up "in the right place" to support fiscal decentralization.

Will a country's decentralization structure evolve to the same place no matter how its introduction is sequenced? Not likely, we think. And if one believes that decentralization is on the government's policy agenda to achieve a specific set of objectives, one will conclude that sequencing matters.

The second reason is that even if one could eventually reach a "good" decentralization structure by making policy decisions on an opportunistic basis, there are considerable costs to be borne. Some of these are the costs of the inefficiencies introduced by unplanned (and perhaps unwise) interim decisions that might be made as a result of political influences.

Take the case of the U.S. and other decentralized industrial countries. Many of them arrived at their current decentralization status after long and tortuous histories of constitutional debate and other forms of political friction and countless economic inefficiencies and fiscal troubles. It is unlikely that developing countries in the process of decentralization today could afford to spend the time and the resources that it took many of these industrialized countries to complete their decentralized systems. As is the case for many policy issues, the example provided by many industrialized countries as regards the sequencing of decentralization is one of how not to do things.

Third, there is the cost of undoing a culture that is out of step with decentralization. For example, when countries adopt interim measures that lead to soft budget constraints and near-total revenue reliance on transfers from higher level governments, it creates a sense of dependency, and a feeling that the financing of 
government services is a function that "belongs" to the higher level government. What makes matters worse is that both central and subnational governments can come to accept this culture. As many countries have learned, it is extremely hard to move away from the culture of dependency.

\subsection{Sequencing Matters}

The alternative approach is the one we argue, that countries are better off if they plan their decentralization policy and properly sequence its introduction. There are a number of arguments to support this. From an organizational viewpoint the rationale is based on two sets of arguments.

First, the transition costs or friction costs will be less under a planned system, because the pieces of the decentralization policy are more likely to fit together, and because there may be less chance for policy or administrative mistakes to be made. Moreover there is less likelihood of having to undo mistakes of the interim period. As noted above, these mistakes can be very costly in terms of resources lost and in terms of a loss in confidence in the decentralization program.

Second, a proper ordering of decentralization allows government to keep its eye on the future, and on the plan for the continued evolution of fiscal decentralization. It is much better to tag reforms on to an existing framework than to start off in new directions that may not fit. And, it is much better to anticipate implementation problems than to discover them in the process of implementation. For example, under a planned development of decentralization, capacity development at the local government level might begin early or be phased in under an asymmetric plan. Under the "make it up as you go" approach, capacity development may be ignored for years and then found wanting at the time policy points to granting more expenditure responsibility to local governments.

In addition to facilitating the implementation of decentralization policy, proper sequencing can also help avoid significant costs that can otherwise result ranging from inefficient allocation of resources to macroeconomic instability. Although it may not always be simple to disentangle the cause-effect link between sequencing and other aspects of the decentralization policy, the potential negative effects of poor sequencing can be, as we argue below, quite serious. The potentially large costs of deviating from proper sequencing beg the question of why countries do so.

\subsection{Why Do Countries Deviate from Optimal Sequencing?}

There are many possible reasons why so many countries appear to be out of step with what we see to be the normative, textbook approach. Two would seem especially noteworthy. First, the desirable sequence is complex and too demanding in design. Fiscal planners in developing countries aren't willing to take this on. Second, sequencing requires a sustained discipline and vision for its implementation, and this requires overcoming pressures from political actors. 
In terms of design, governments may simply lack the information or awareness of the desirability and convenience of the proper sequencing for their decentralization policy. This is likely to be a powerful explanation. In practice, policymakers appear to make more obvious and immediate mistakes in fiscal decentralization design, such as providing negative incentives to revenue mobilization in transfer systems, or decentralizing revenues without having assigned expenditure functions to local governments. Thus, it should not be surprising that they will not be knowledgeable or aware of the more complex concept of proper sequencing. Little has been written and less publicized on this issue in the academic and policy literatures on fiscal decentralization.

Policymaking in real life, as opposed to a textbook scenario, is subject to long lists of powerful, political and institutional constraints. One set of political constraints has to do with special windows of opportunity for the introduction of substantial reforms provided by changes in political regime or the threat of such changes. It can be perfectly rational for policymakers to take advantage of these windows of opportunity knowing that they are shortchanging the process and that the outcome may be less than perfect and that it will need "repairs" in the future. A related set of political constraints has to do with the average period governments are in power; for example, a four year election cycle may not be long enough to see the results of a decentralization reform, and therefore the temptation will arrive to short-circuit the proper sequence. In general, one would expect countries with less stable political regimes to breach the desirable sequence for decentralization more often than countries with more stable governments.

Numerous institutional constraints can bind governments to breach the desirable sequencing of fiscal decentralization. Besides political costs in coalition governments and relative administrative ease, policymakers may be forced to balance tradeoffs involving existing administrative capacity, regional equity issues, lack of accountability mechanisms at the local level, and reform thrusts in other policy areas, such as tax policy or civil service.

\section{4. $\quad$ Risks Associated with Sequencing Mistakes}

Conceptually, one could attempt to quantify the potential risks associated with sequencing mistakes as being proportionate to the size of the "contingent liability" associated with decentralization reform i.e., the relative share of fiscal resources being decentralized. This would become a liability to the public sector if the reform is unsuccessful. As a first, rough approximation, we might think about quantifying the expected risk as the product of this liability and the likelihood or probability of failure implied by the particular sequencing misstep. As such, fiscal decentralization reforms that involve fewer budgetary resources, or minor taxes and no borrowing authority (rather than major expenditure responsibilities, major taxes, and borrowing powers) are fiscally less risky. Proposed reforms that have major obstacles in implementation (e.g., reforms that require significant reform of regulatory processes and procedures) have a higher probability of failure resulting in potentially greater fiscal risks.

Of course, one way to minimize the risks associated with fiscal decentralization is to reduce its scope. Think small. But in doing so the country forgoes large potential 
benefits also associated with decentralization. Some analysts, and politicians, might see another way to minimize risks as to design and implement only small parts of the program and take a piecemeal approach to decentralization. But if the full system is not designed, the pieces may not fit together in this process and the costs (risks) go up.

Clearly, there is a tradeoff between risks and benefits of decentralization and where a particular country lands on that line will depend on how risk averse government feels it needs to be. In the aftermath of Suharto, Indonesia was in a position where the introduction of fiscal decentralization had become a much less risky proposition than in the past, so a big bang approach became politically feasible. India's state deficits may be forcing more risky approaches to fiscal decentralization. But Russia seems to be moving in the direction of recentralizing and minimizing risks.

A quantification of the general risks associated with sequencing mistakes will not be attempted here. We focus instead on qualitative assessment of the risks associated with the common missteps or deviations from our normative blueprint for sequencing. For example, what are the risks of a program that is implemented before it is fully designed, as in Indonesia's big bang? What are the consequences of fixing revenue entitlements before fixing expenditure responsibilities (Brazil) or giving subnational governments borrowing authority without imposing a hard budget constraint on them (India)?

In offering policy advice to countries about sequencing issues, it is important to distinguish between what is a high risk mistake versus what is lower risk mistake. The two classes of risks associated with different sequencing mistakes are outlined below.

\section{High-Risk Sequencing Choices}

Mistakes in sequencing can impose serious costs on society, as noted above. However, not all missteps will have similarly significant consequences. The costs of a poorly sequenced decentralization program can range from ineffectiveness and subsequent failing support of decentralization efforts, to macroeconomic instability and even chaotic situations and fundamental failure in public sector delivery, to minor delays and confusion about responsibilities. The specific consequences of a particular misstep in the sequencing design of decentralization reform are particular to each country. Still, some general principles about these risks, and about the cost of recovering from sequencing mistakes, can be enumerated.

Failing to develop a comprehensive policy document that defines a framework for the fiscal decentralization. This is perhaps the most controversial of sequencing rules, probably because so much political capital must be used up in making the overall plan transparent. But most hard policy decisions are politically difficult, and the view here is that the consequences and costs of not taking on this risk at an early stage are quite significant.

If the overall framework is not developed, the decentralization law will lack a foundation, implementation will lead policy, the decentralization strategy will drift and lose focus, and it will not likely achieve the objectives that have been set for it. There 
will be resource costs associated with refitting the program because some of the policy pieces have failed. Moreover, the time cost of piecemeal design can be significant, e.g., years of equalization in local government capacity development might be lost.

Failing to install a hard budget constraint on subnational governments. By creating a culture of dependency, the government creates a long term problem with fiscal discipline, and one that is difficult to deal with as time goes on. Local officials, especially elected local officials with short time horizons, much prefer to finance expenditures with grants from higher level governments than to raise taxes, and much prefer borrowing vs. financing services with current revenues. At the extreme, the absence of a hard budget constraint together with a delinking of borrowing from the creditworthiness criteria can invite serious macroeconomic stability problems.

Getting the "finance follows function" rule out of order. Not developing a clear set of expenditure assignments before developing revenue assignment and a vertical share of transfers is a mistake that continues to plague decentralization programs. This leads to inefficiencies in service delivery, unwanted fiscal disparities and is an enemy of the hard budget constraint. In some cases, it will lead to central deficits and macroeconomic instability. This is the most common of the sequencing mistakes. It is the rare decentralization program around the world that does not feel constrained by an unclear or inappropriate expenditure assignment. As problematic a situation is to reassign expenditure responsibilities to subnational governments or impose (unfunded) mandates without assigning appropriate revenues to finance these new functions.

Passing the decentralization law, or placing decentralization provisions in the Constitution, before developing the objectives and framework, i.e., the plan for decentralization. This can carry great consequences, especially if constitutional provisions get out in front of a clearly thought out set of goals for the decentralization. The consequence of this misstep in sequencing can be an intergovernmental structure that encourages fiscal indiscipline, an assignment of revenues and expenditures that do not match and cannot easily be changed, and an inflexible system that is outgrown by the economy. The costs may be the instability that comes with fiscal deficits at the subnational government level, service levels that are made more inadequate by the mismatch between resources and expenditure responsibilities, and unwanted fiscal disparities.

Failing to develop a clear set of implementing regulations, based on the decentralization law and done prior to implementation, creates a variety of significant problems including, various levels of government choosing the method of implementing the decentralization that best suits their interests, to costly use of resources, and to inefficiency in service delivery.

Failing to put in place a capacity development program for subnational governments. A best route is to begin preparing local governments for their new responsibilities as soon as possible in the process of decentralization. The longer one waits to begin this process, the longer the time before local governments can assume new 
responsibilities for fiscal leadership. The lack of capacity development can lead to incomplete decentralization programs, for example, those that stall at the intermediate level of government and never reach the local level.

\section{Lower Risk Sequencing Mistakes}

Certain other deviations from an optimal ordering of decentralization policy and implementation impose costs, but are lower risk in that they can be more easily corrected.

Moving forward with decentralization without a deconcentrated system of service delivery in place. As noted above, deconcentration quite likely makes it easier to decentralize service delivery responsibility to subnational governments but it is not an absolutely necessary intermediate step. Local government capacity can be developed independent of deconcentration.

Another concern is that effective deconcentration might crowd out decentralization, by reducing the demand for local control. This might not be a risk. Deconcentration may seek local inputs in deciding, for example, on investment allocations, but central officials operating in the local area are still accountable upward to higher level governments rather than downward to voters. Deconcentration would seem a weak substitute for decentralization.

Failing to provide subnational governments with significant revenue-raising autonomy. It is the rare developing country that assigns significant taxing powers to subnational governments at the onset of decentralization. Getting buy-in on this from the central government, and getting proper capacity developed at the subnational level are stumbling blocks that would seem no more severe many years into a decentralization program that at the outset. However, a culture of dependency does take hold, and subnational governments do become accustomed to an intergovernmental system where they rely on central transfers. The accountability that comes with local revenue raising is lost and is another component of this culture of dependency. The better route is to lay out the plan for local government financing as part of the general strategy for decentralization. That is perhaps the one time that all of the possible options can be placed on the table. The costs arising from the lack of revenue autonomy are likely to increase over time.

Failing to provide borrowing powers to subnational governments. Clearly it is desirable to set up a regime for creditworthy subnational governments to finance capital facilities with debt. If the borrowing program is not set up at the outset, this raises some efficiency costs that might have been avoided (e.g., under-financing long lived assets from current account revenues). But the later introduction of borrowing powers is a sequencing mistake of lesser order. The introduction of borrowing powers without a hard budget constraint, as noted above, is a sequencing mistake of a major order.

\section{Lacking a national debate to gain consensus about decentralization policy.} Obviously, consensus is important, and support for a program can be developed by allowing a broad range of inputs. But in fact, many countries do not have such a national 
debate, unless it is forced. The absence of a national consensus may endanger the sustainability of fiscal decentralization.

Failing to establish a monitoring and evaluation system. It is important to set this up at the outset so that the decentralization program can be monitored and evaluated, and possibly fine-tuned with policy adjustments. However, it can be set up at a later point in the process, and this is in fact the case in many countries. The costs implied are the failure to catch problems in the early stages, and the limited information that is available to politicians as they make changes in the system. 


\section{References}

Alm, James, Robert H. Aten and Roy Bahl. 2001. "Can Indonesia Decentralize Successfully? Plans, Problems and Prospects.” Bulletin of Indonesian Economic Studies 37 (1): 83-102.

Arikan, G. Gulsun. 2004. “Fiscal Decentralization: A Remedy for Corruption?” International Tax and Public Finance 11: 175-1995.

Arze, Francisco Javier and Jorge Martínez-Vazquez. 2004. "Descentralización desde la Perspectiva de Países Pequeños: Bolivia, El Salvador, Ecuador y Nicaragua,” with Javier Arze. Gestión y Política Pública, 13 (3).

Bahl, Roy. 1999a. Fiscal Policy in China: Taxation and Intergovernmental Fiscal Relations. South San Francisco: The 1990 Institute. . 1999b. "Implementation Rules for Fiscal Decentralization.” Public Budgeting and Finance 19 (2): 59-75.

Bahl, Roy, Jameson Boex, and Jorge Martinez-Vazquez. 2001. Intergovernmental Fiscal Transfers: The Design and Implementation of Intergovernmental Fiscal Transfers. Monograph. Atlanta: Andrew Young School of Policy Studies, Georgia State University.

Bahl, Roy and Jorge Martinez-Vazquez. 2005. "Fiscal Decentralization and Economic Reform in China.” In T.S. Srinivasan and Jessica Wallack, eds., The Dynamics of Federalism: The Political Economy Reality, Oxford Economic Press.

Bahl, Roy and Johnannes F. Linn. 1992. Urban Public Finance in Developing Countries. World Bank. New York, N.Y.: Oxford University Press.

Bird, Richard, Robert Ebel, and Christine Wallich, eds. 1995. Decentralization of the Socialist State. Washington, D.C.: World Bank.

Bird, Richard and Robert Ebel, eds. Asymmetric Federalism. Washington, D.C.: World Bank, forthcoming.

Boex, Jameson and Jorge Martinez-Vazquez. 2004. "Developing the Institutional Framework of Intergovernmental Fiscal Relations in Decentralizing LDCs.” International Studies Program Working Paper 04-02, Atlanta: Andrew Young School of Policy Studies, Georgia State University.

. Forthcoming. Local Government Finance Reform in Developing Countries: The Case of Tanzania. Palgrave Macmillan Limited.

Boex, Jameson, Jorge Martinez-Vazquez, and Andrey Timofeev. 2005. “A Review of Fiscal Decentralization Reform in Selected Transition Economies: The Status of Reforms and Opportunities for the Way Forward.” A report to the UNDP, Bratislava.

Burki, Shahid J., William Dillinger., Guillermo Perry, et. al. 1999. Beyond the Center: Decentralizing the State in Latin America. Washington, D.C.: World Bank.

Courchene, Thomas, Alberto Diaz-Cayeros, and Steven Webb. 2000. "Historical Forces: Geographic and Political.” In Marcelo Giugale, and Steven B. Webb, eds. Achievements and Challenges of Fiscal Decentralization: Lessons from Mexico. Washington, D.C.: World Bank.

Davoodi, Hamid and Heng-fu Zou. 1998. "Fiscal Decentralization and Economic Growth: A Cross-Country Study.” Journal of Urban Economics 43 (2): 244-57.

Evans, Anne and Nick Manning. Sept. 2004. "Administrative Decentralization: A Review of Staffing Practices During Decentralization in Eight Countries.” Draft Study prepared for The World Bank.

Fisman, Raymond and Roberta Gatti. 2002. "Decentralization and Corruption: Evidence Across Countries.” Journal of Public Economics 83: 325-345.

Giugale, Marcelo, Vinh Nguyen, Fernando Rojas, and Steven B. Webb. 2000. “Overview.” In Marcelo M. Giugale. and Steven B. Webb, eds. Achievements and Challenges of Fiscal Decentralization: Lessons from Mexico. Washington, D.C. : The World Bank. 
Giugale, Marcelo and Steven B. Webb, eds. 2000. Achievements and Challenges of Fiscal Decentralization: Lessons from Mexico. Washington, D.C. : The World Bank.

Government of Tanzania. 2004. Local Government Fiscal Review 2004.

Gramlich, Edward M. 1993. “A policymaker's guide to fiscal decentralization.” National Tax Journal. 46 (2): 229-235.

Gurgur, Tugrul, and Shah, Anwar S. 2000. "Localization and Corruption: Panacea or Pandora's Box.” Presented at the IMF Conference on Fiscal Decentralization, November 21, 2001. Washington D.C.

Hofman, Bert and Kaiser, Kai. 2004. “The making of the 'Big Bang' and its aftermath: a political economy perspective.” In James Alm, Jorge Martinez-Vazquez and Sri Mulyani Indrawati, eds., Reforming Intergovernmental Fiscal Relations and the Rebuilding of Indonesia: The 'Big Bang' Program and Its Economic Consequences. Studies in Fiscal Federalism and State-Local Finance In Wallace E. Oates, series ed. Northampton, Massachusetts: Edward Elgar Publishing Limited.

Lin, Justin Yifu and Liu, Zhiqiang. 2000. "Fiscal Decentralization and Economic Growth in China.” Economic Development and Cultural Change. 49 (1): 1-22.

Local Government Reform Programme. 1998. "Policy Paper in Local Government Reform.” Ministry of Regional Administration and Local Government, Republic of Tanzania, (October).

Martinez-Vazquez, Jorge. 2002. “Asymmetric Federalism in the Russian Federation: Cure or Poison?” International Studies Program Working Paper 02-04. Atlanta: Andrew Young School of Policy Studies, Georgia State University. In Richard Bird and Robert Ebel, eds. Asymmetric Federalism. Washington, D.C.: World Bank.

Martinez-Vazquez, Jorge. 2004. "Making Fiscal Decentralization Work in Vietnam.” A Report for Vietnam's Public Expenditure. Washington, D.C.: World Bank.

Martinez-Vazquez, Jorge and Jameson Boex. 2001. Russia's Transition to a New Federalism. World Bank Institute Learning Resources Series, Washington D.C.: The World Bank.

Martinez-Vazquez, Jorge \& McNab, Robert. 2000. "Fiscal Decentralization and Economic Growth.” International Studies Program Working Paper. Atlanta: Andrew Young School of Policy Studies, Georgia State University.

. 2003. "Fiscal Decentralization and Economic Growth.” World Development, 31 (9) (Spring): 1597-1616.

. 2005. "Fiscal Decentralization, Macroeconomic Stability and Economic Growth.” International Studies Program Working Paper 05-06. Atlanta: Andrew Young School of Policy Studies, Georgia State University.

Martinez-Vazquez, Jorge, Baoyun Qiao, and Daoshu Wang. 2005. “Some Unwanted Consequences of Fiscal Decentralization in China: Subnational expenditures on Health and Education.” International Studies Program Working Paper. Andrew Young School of Policy Studies, Georgia State University.

Martinez-Vazquez, Jorge and Andrey Timofeev. 2005. "Choosing between Centralized and Decentralized Models of Tax Administration.” International Studies Program Working Paper 05-02. Atlanta: Andrew Young School of Policy Studies, Georgia State University.

McLure, Charles, and Jorge Martinez-Vazquez. 2000. "The Assignment of Revenues and Expenditures in Intergovernmental Fiscal Relations.” Paper prepared for the core course on Intergovernmental Relations and Local Financial Management, World Bank Institute, Washington, D.C.: World Bank.

McMillan, J. 2004.”Avoid Hubris and Other Lessons for Reformers.” Finance and Development (September), 34-37.

Ministry of Finance. 2002. "Fiscal Decentralization White Paper.” Draft. Government of Indonesia (February 20). 
Montinola, Gabriella, Yingyi Qian, and Barry R. Weingast. 1995. "Federalism, Chinese Style: The Political Basis for Economic Success in China.” World Politics, 48 (1) (October).

NCG. 2004. "A Comparative Analysis of Experiences From Decentralization in Kenya, Tanzania and Uganda.” Draft Synthesis Report supported by Danish Trust Fund and World Bank, Dar Es Salaam (June).

Oates, Wallace E. 1999. “An Essay on Fiscal Federalism.” Journal of Economic Literature, 37 (3): 1120-1149.

Qian, Yingyi and Barry R. Weingast. 1996. “China’s Transition to Markets: Market-Preserving Federalism, Chinese Style.” Journal of Policy Reform, 1: 149-185.

Qiao, Baoyun, Jorge Martinez-Vazquez, and Yongsheng Xu. (2004) "The Tradeoff between Growth and Equity in Decentralization Policy: China’s Experience.” International Studies Program Working Paper. Atlanta: Andrew Young School of Policy Studies, Georgia State University.

Rao, M. Govinda. 2000. "Fiscal Decentralization in Indian Federalism.” Bangalore: Institute for Social and Economic Change.

Rao, M. Govinda and Tapas Sen. 1996. Fiscal Federalism in India: Theory and Practice. Delhi: McMillan India Limited.

Rao, M. Govinda and Singh, Nirvikar. 2004. The Political Economy of Federalism in India. Oxford: Oxford University Press.

Rasyid, M. Ryaas. 2004. "The policy of decentralization in Indonesia.” In James Alm, Jorge Martinez-Vazquez and Sri Mulyani Indrawati, eds., Reforming Intergovernmental Fiscal Relations and the Rebuilding of Indonesia: The 'Big Bang' Program and Its Economic Consequences. Studies in Fiscal Federalism and State-Local Finance In Wallace E. Oates, series ed. Northampton, Massachusetts: Edward Elgar Publishing Limited.

Rodden, Jonathan. 2003. "Fiscal and Bailouts in Brazil.” In Jonathan Rodden, G. Eskeland and Jennie Litvak, (eds.). Fiscal Federalism and the Challenge of Hard Budget Constraints, Cambridge, Mass: MIT Press, 213-248.

Rodden,Jonathan, Gunnar Eskeland and Jennie Litvack. (2003). “Introduction and Overview.” In Jonathan Rodden, G. Eskeland and Jennie Litvak, (eds.). Fiscal Federalism and the Challenge of Hard Budget Constraints, Cambridge, Mass: MIT Press, 213-248.

Rodden, Jonathan and Erik Wibbels. 2002. "Fiscal Federalism and the Challenge of Hard Budget Constraints: Beyond the Fiction of Federalism: Macroeconomic Management in Multitiered Systems.” World Politics, 54 (4): 494-531..

Sethi, Geeta, ed. 2004. Fiscal Decentralization to Rural Governments in India. Washington, D.C.: World Bank.

Shah, Anwar. 1999. "Fiscal federalism and macroeconomic governance: For better or Worse,” in K. Fukasaku, \& de Mello, Luiz R, Jr. (eds.), Fiscal Decentralisation in Emerging Economies: Governance Issues, Washington, D.C.: Organization for Economic Cooperation and Development, 37-54.

Simanjuntak, Robert A. and B. Raksaka Mahi. 2004. "Local tax revenue mobilization in Indonesia’s decentralizing era.” In James Alm, Jorge Martinez-Vazquez and Sri Mulyani Indrawati, eds., Reforming Intergovernmental Fiscal Relations and the Rebuilding of Indonesia: The 'Big Bang' Program and Its Economic Consequences. Studies in Fiscal Federalism and State-Local Finance In Wallace E. Oates, series ed. Northampton, Massachusetts: Edward Elgar Publishing Limited.

Singh, Nirvikar. 2004. “India’s System of Intergovernmental Fiscal Relations.” Department of Economics Working Paper 578, University of California, Santa Cruz.

Spahn, Paul Bernd. 2005. "Strategies for Decentralizing Government While Maintaining Stability.” Working Paper. 
Tiebout, C. 1956. “A Pure Theory of Public Expenditures.” Journal of Political Economy 64, 416-424.

Wallich, Christine. 1994. Russia and the Challenge of Fiscal Federalism, Washington, DC: World Bank.

Webb, Steven B. and Gonzalez, Christine Y. 2003. "Bargaining for a New Fiscal Pact in Mexico.” Washington, D.C.: The World Bank.

Wong, Christine. 1998. "Municipal Finance in China: The Development of Extra-Budgetary Revenues.” Paper presented at International Municipal Finance Forum. Washington, D.C.: The World Bank (April 15-16).

World Bank. 1997. "Report and Recommendation of the President of the International Bank for Reconstruction and Development to the Executive Directors on Four Proposed Second Provincial Reform Adjustment Loans in the Amount of US\$75 million, US\$75 million, US\$50 million, and US\$100 million to the Argentine Republic to Support Four Reforming Provinces Rio Negro, Salta, San Juan, and Tucuman.” Washington, DC: The World Bank.

World Bank 2000. "Entering the 21st Century: World Development Report 1999/2000." Oxford University Press.

World Bank. 2004. "World Development Indicators." CD.

World Bank. 2004. "State Fiscal Reforms in India - Progress and Prospects". World Bank Partnership for India. New Delhi.

Zhang, Tao and Heng-fu Zou. 1997. "Fiscal Decentralization, the Composition of Public Spending, and Regional Growth in India.” Development Research Group Working Paper. Washington, D.C. World Bank. . 1998. "Fiscal Decentralization, Public Spending, and Economic Growth in China." Journal of Public Economics. 67 (2): 221-40. 